\title{
تصنيف وتأهيل المقاولين في المثاريع الحكومية بالمملكة العربية السعودية
}

عبد الله بن ناصر الدبيان

$$
\text { طالب ماجستير }
$$

| - أستاذ مشارك

قسم العمارة وعلوم البناء، كلية العهارة والتخطيط، جامعة الملك سعود، المملكة العربية السعودية

ملخص البحث. تهتم المملكة العربية السعودية بمشاريع التنمية العمرانية وتحسين وتطوير البنية التحتية،

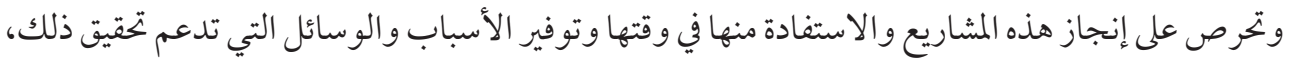

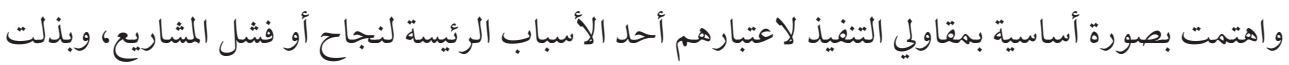

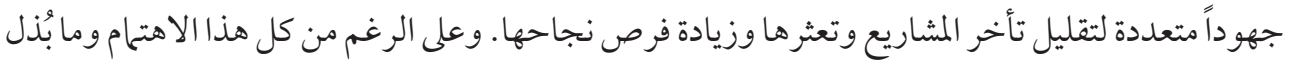

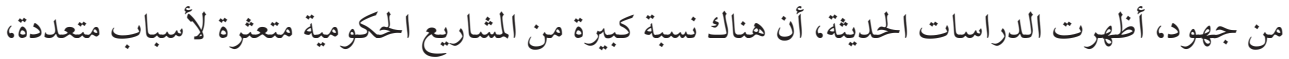

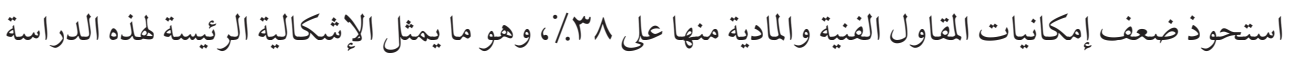

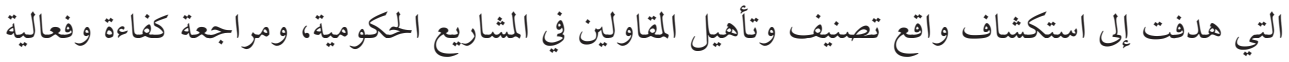

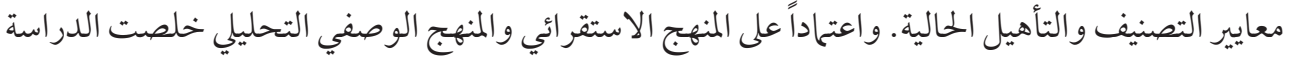

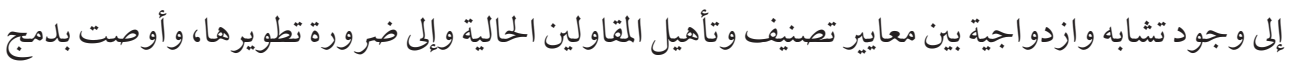

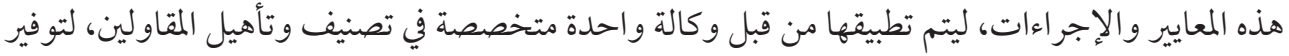

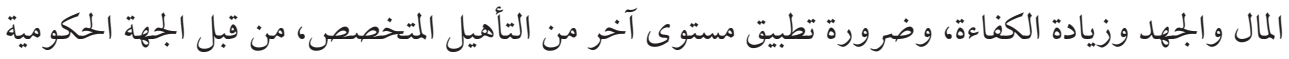

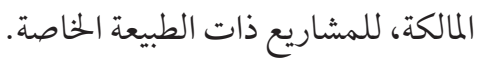

الكلمات المفتاحية: المشاريع الحكومية، تأهيل المقاولين، تصنف المقاولين، وكالة تصنيف المقاولين، الهيئة

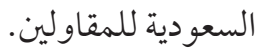


أسـبـاب تعثــــ المشــاريع هـــو ضعـف الإمكانيـات

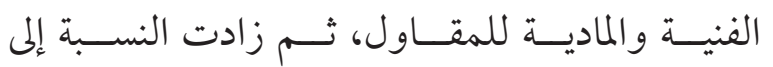
بحسبــ مـا ذكـرت الهيئـة العليـا لتطويـر

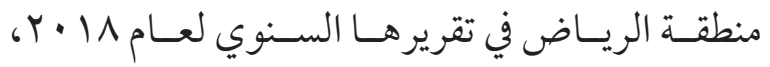

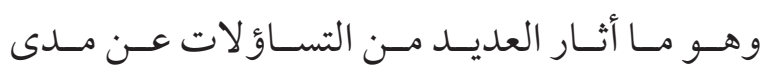
كفـاءة وفعاليـة عمليـات تصنيـف وتأهيـل المقاولـين

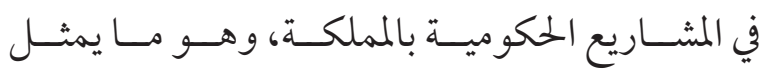

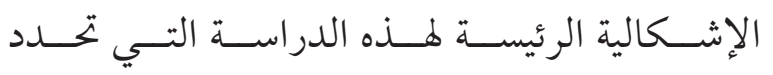

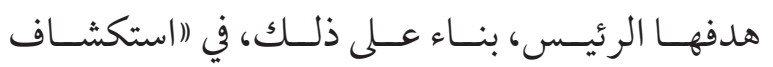
واقـع تصنيـف وتأهيـل المقاولـين بالمملكــة العربيـة

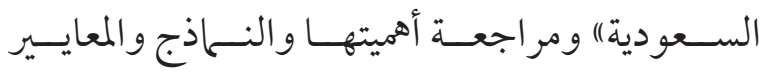

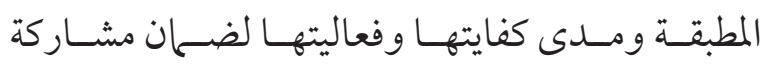

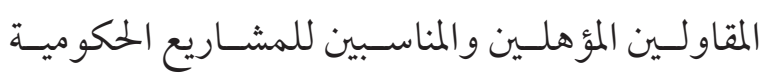

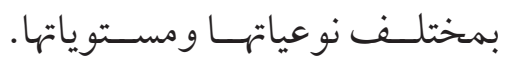

وتنبــح أهميـة الدراسـة مــن توافـق أهدافهــا مـع أهــداف وتوجهـات المملكــة العربيـة السـعودية

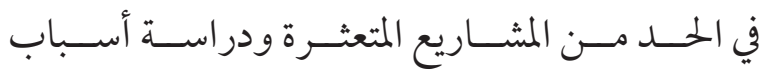

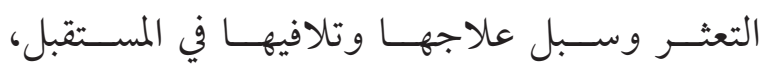
ولتحقيــق الاسـتفادة مــن المشــاريع في وقتهــــا

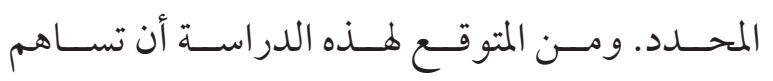
في دعــم جهــود وكالـة تصنيـف المقاولـين وجهــود الميئــة الســعودية للمقاولــين في تحســــن كفــاءة

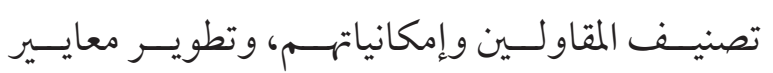
تأهيـل المقاولـين في نمــوذج التأهيـل الخـاص بنظــام

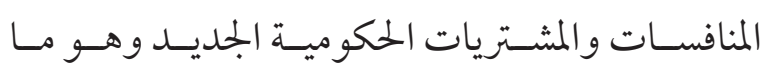

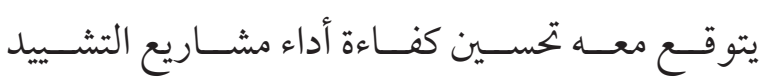

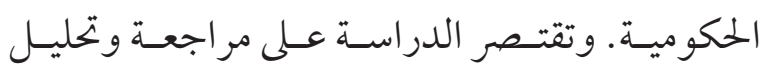

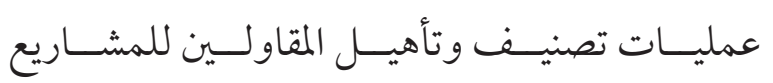

ا ـ التمهيد والمقدمات البحثية للدراسة

بــــأت مشــاريع التنميــة الاقتصاديــة و الاجتحاعيـة بالمملكــة العربيـة السـعودية في التوسـع

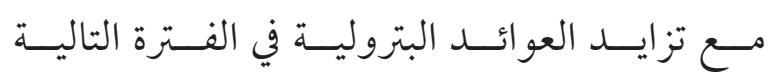

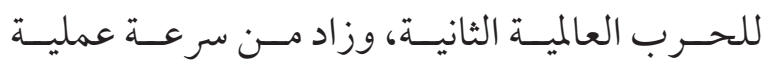

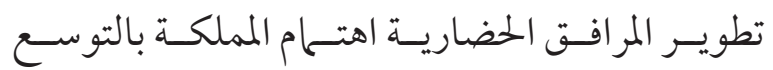

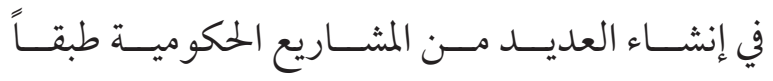

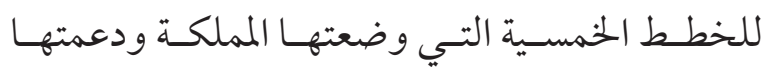
المخصصــات الماليـة الضخمــة التسي وفرتهـا المملكــة

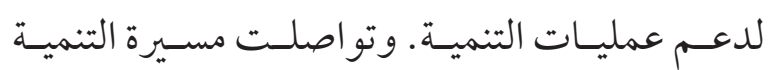

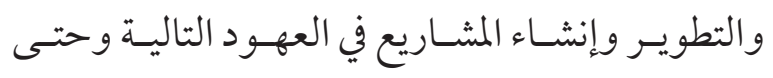

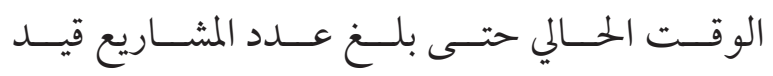

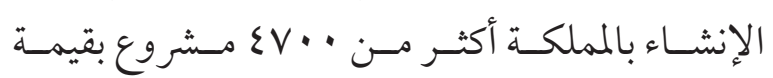

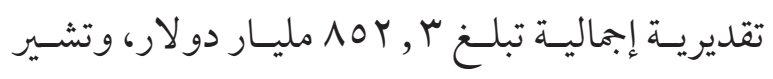

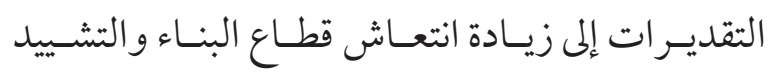

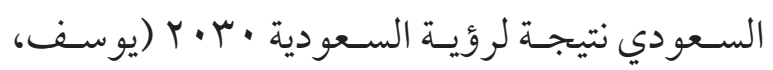

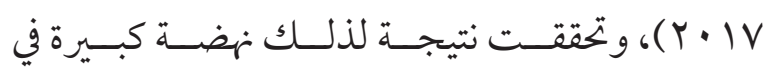
العديــد مــن القطاعــات الحيويــة.

عـلى الرغــم مــن التوســـع في مشروعـــات

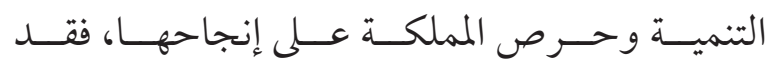
كشـف تقريسر صـادر عـن برنامــج متابعـة مشـاريع

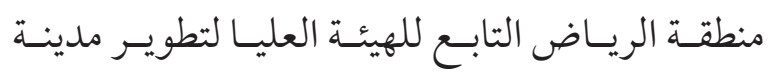

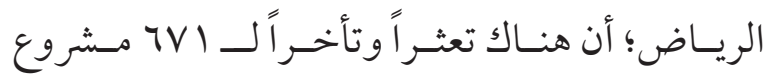

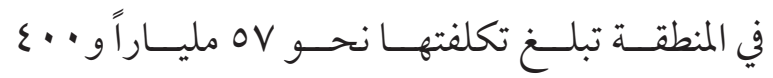

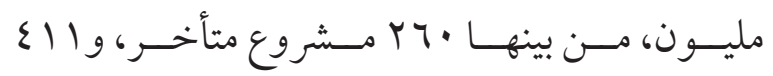

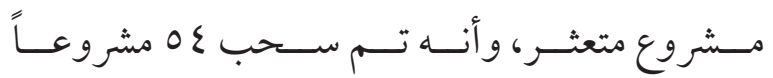

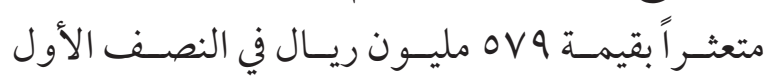

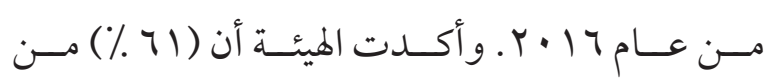


والحــدود الماليـة لهـا وتطويرهــا كلــا دعـت الحلاجـة

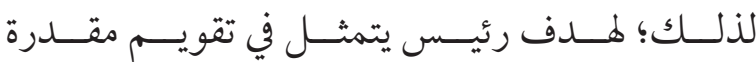

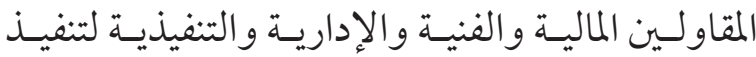

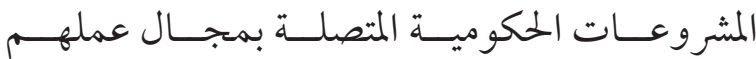

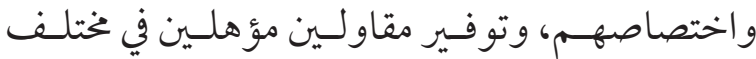

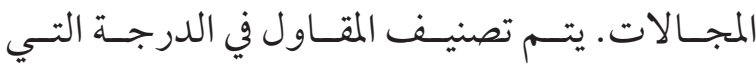

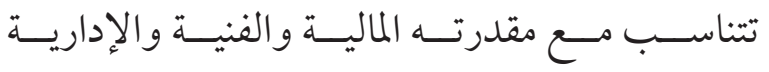

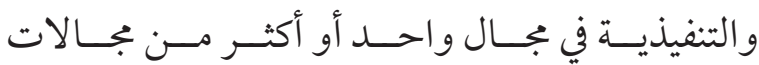
التصنيـف، وذلـك وفقــاً للعنــاصر و المعايـير التـي

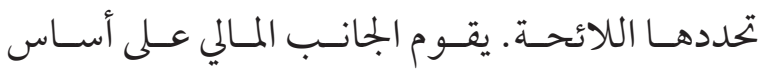

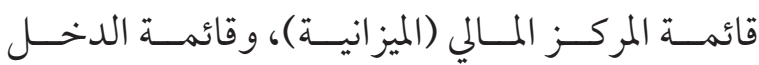

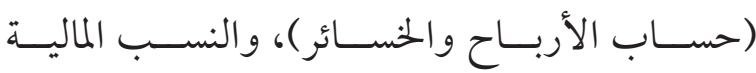

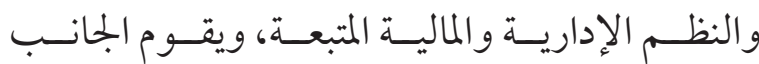

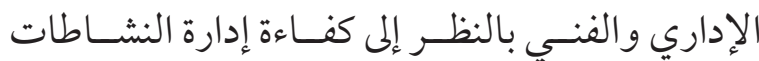

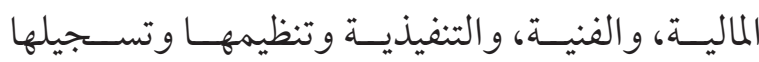

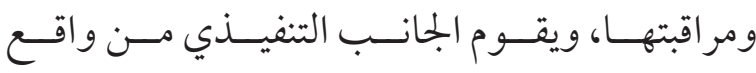
المشرووعـات المنفــة، أو الجــاري تنفيذهـا في القطاعين

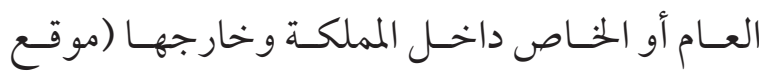

\section{وكالــة تصنيـف المقاولـين).}

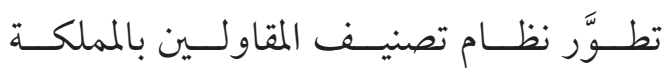

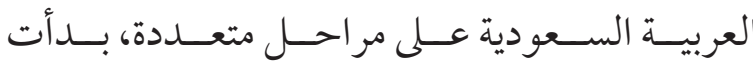

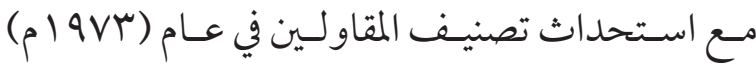

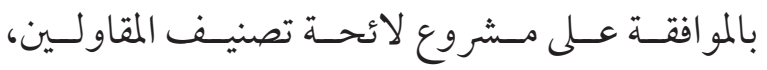

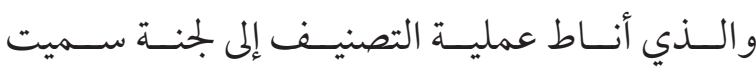

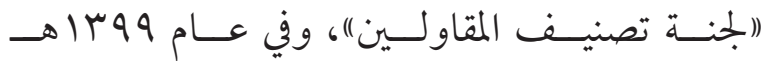

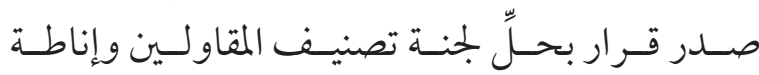

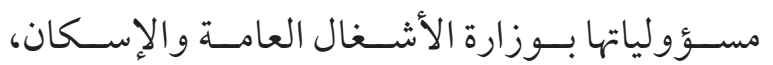

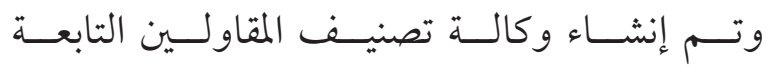

الحكوميـة بالمملكـة العربيـة السـودية، واستكشــاف

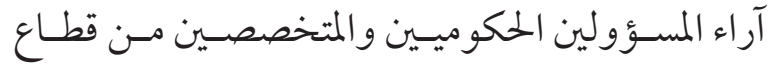
الاستشـارات الهندسية ومـن قطـاع المقـاولات تجـاه

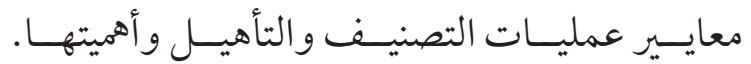
لتحقيـق أهــــاف الدراســة تــم تقسـيمها

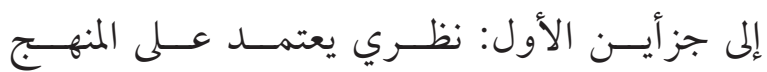

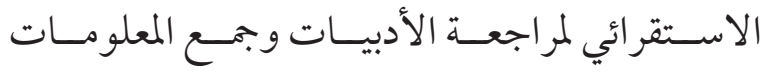

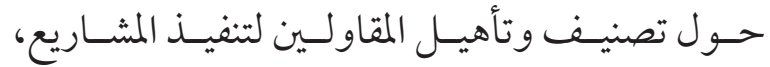

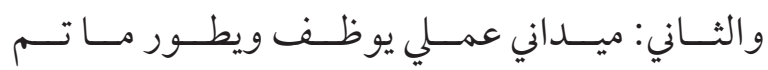

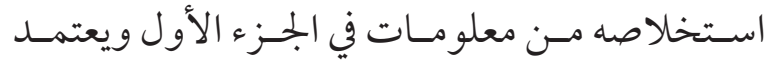

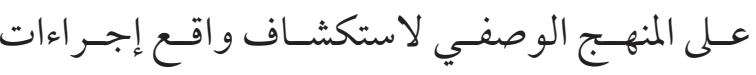

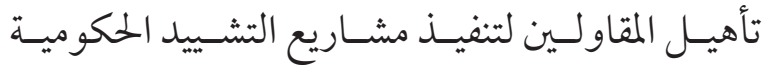

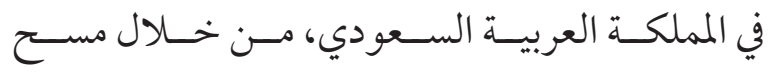

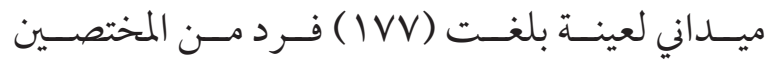

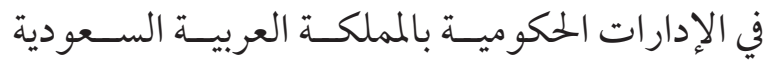

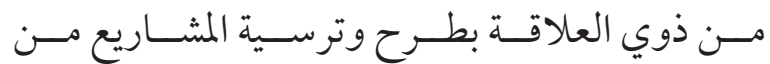

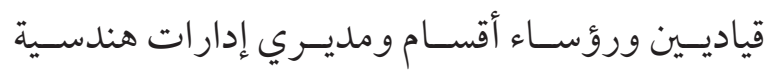

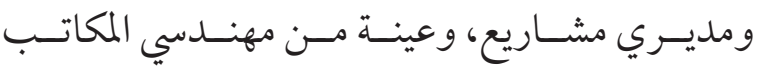

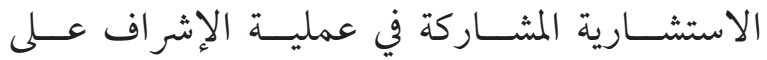

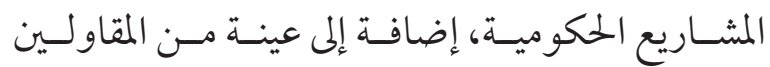

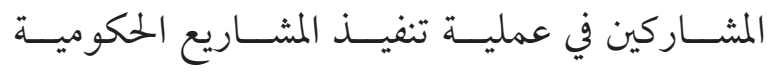

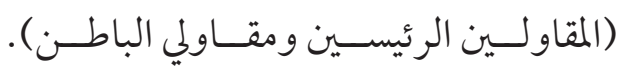

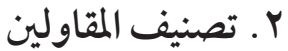

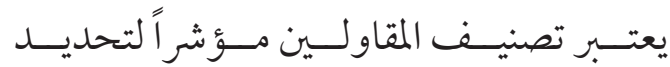

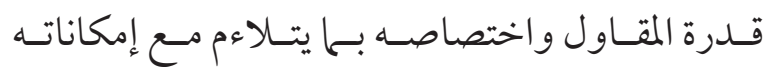
الذاتيــة (الماليــة والفنيــة والإداريــة والتنفيذيــة)،

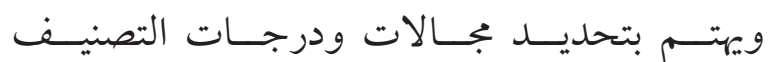


سـابقاً، وإعطـاء صلاحيـات أكـــر لو كالـة تصنيـف

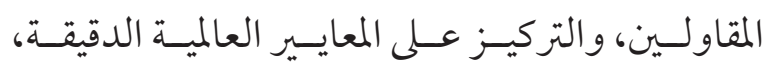

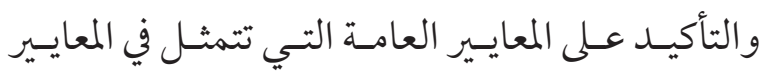

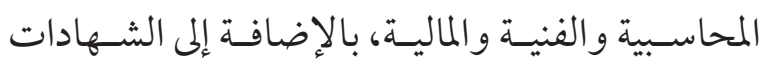

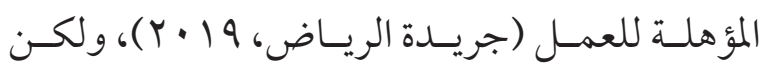

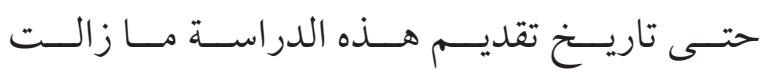

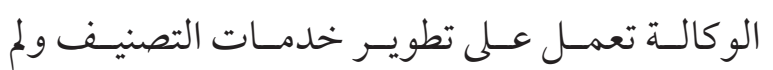

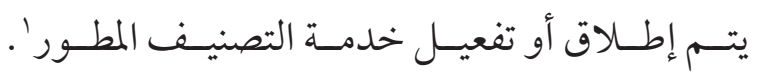

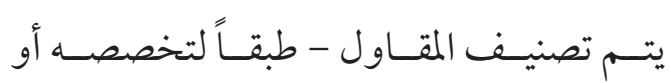

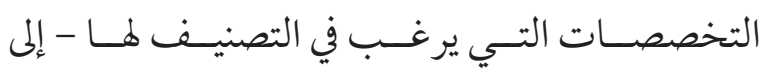

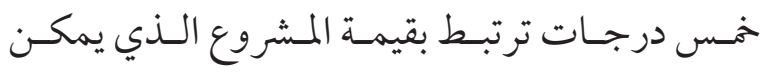

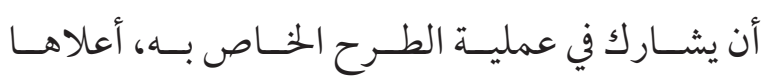

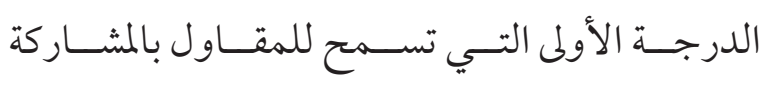

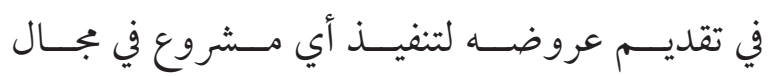

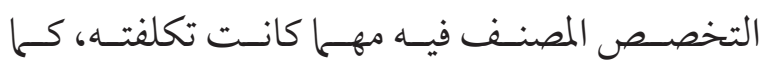
يتضـح مسن الجــدول رقــم (1).
للــوزارة، حيــث قامـت بمتابعـة أعــال تصنيــف المقاولـين. ومـع التطـور الكبير الـذي شـهـدته المملكة

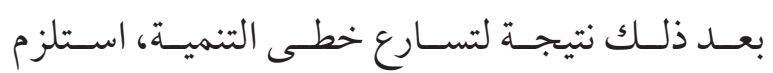

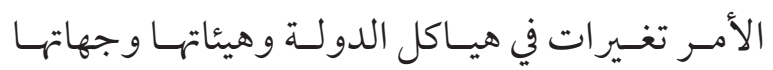

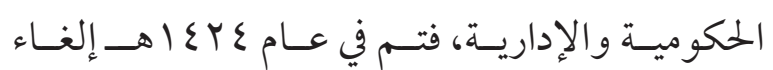

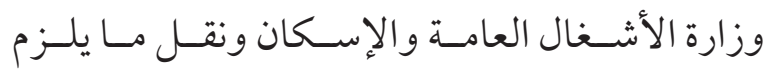

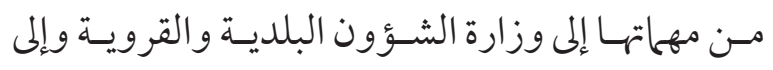

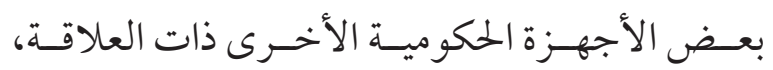

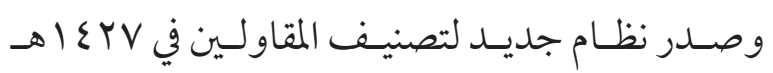

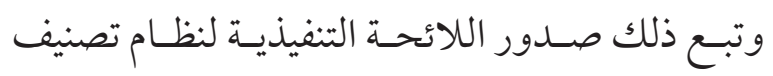

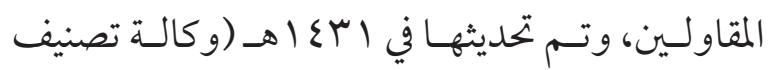

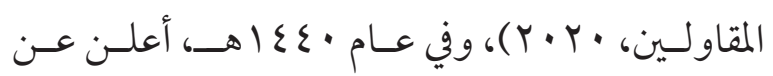

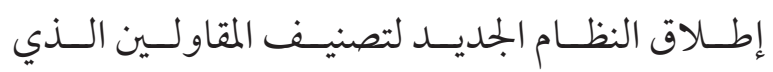

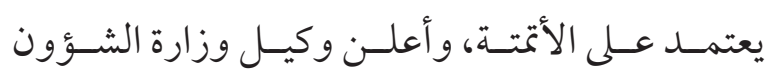

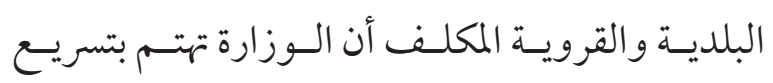
موضـوع تصنيـف المقاولـين بتجــاوز جميـع الأطــر

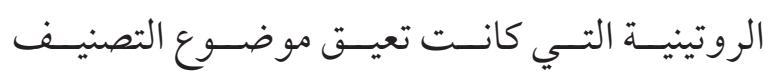

جدول رقم (1) . يوضح بجالات التصنيف ودرجاتها وحدودها المالية

\begin{tabular}{|c|c|c|c|c|c|c|c|}
\hline \multicolumn{8}{|c|}{ جدول يحد ججالات تصنيف المقاولين ودرجات التصنيف وحدودها المالية، والحد الملي الأعلى لقيمة المثروع الواحد الذي مكن إسناده للمقاولين دون تصنيف } \\
\hline \multirow{2}{*}{ الواحد الملي الأعلى لقيمة المشروع تصنيف بملاين } & \multicolumn{5}{|c|}{ درجة التصنيف، والحد الأعلى لقيمة المشروع الواحد بملايين } & \multirow[t]{2}{*}{ 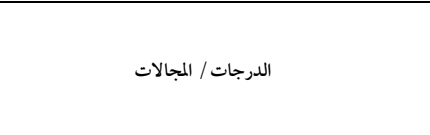 } & \multirow{2}{*}{ الرقم } \\
\hline & الخامسة & الرابعة | & الثالثة & الثانية & الأولى & & \\
\hline 4.2 & 7 & 21 & 70 & 280 & 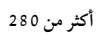 & المباني & 1 \\
\hline 4.2 & 14 & 42 & 140 & 420 & 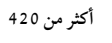 & | الطرق / أعال المياه والصرف الصحي / الأعمال الصناعية / البحرية & 2 \\
\hline 4.2 & 7 & 21 & 70 & 280 & 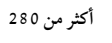 & | الأعمال الكهربائية / الألكترونية / الإتصال / الميكانيكية / السدود & 3 \\
\hline 4.2 & 7 & 21 & 42 & 140 & 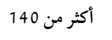 & | تشجير الحدائق وتنظيم المواقع / المسالخ / حفر الآبار & 4 \\
\hline 1.4 & 4.2 & 14 & 42 & 140 & أكثر من 140 & | الصيانة / الصيانة والتشغيل لجميع المجالات & 5 \\
\hline 1.4 & 4.2 & 14 & 42 & 140 & 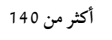 & | نظافة المدن والتخلص من النفايات & 6 \\
\hline 1.4 & 4.2 & 14 & 42 & 140 & أكثر من 140 & تخديم وتأمين التغذية للمر اكز الطبية / الإعاشة للأفراد & 7 \\
\hline
\end{tabular}

(المصدر : لائحة نظام تصنيف المقاولين من موقع الو كالة مع التصرف من قبل الباحث) (1) 


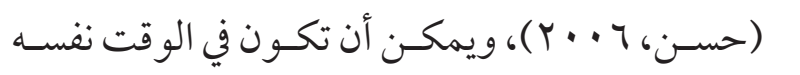

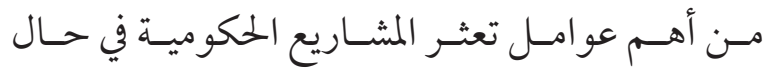

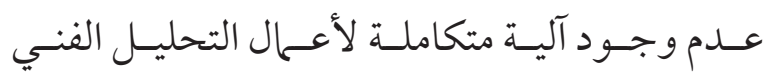

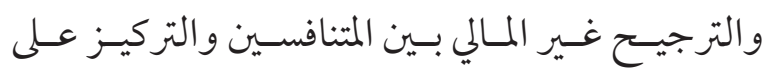

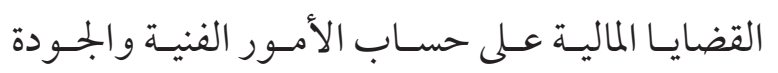

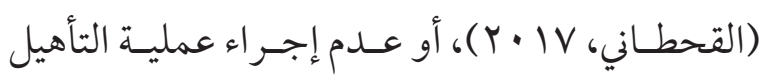

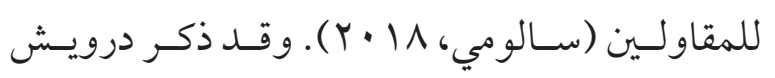

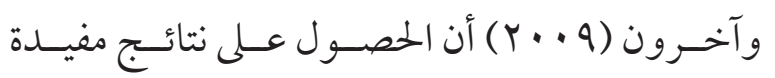

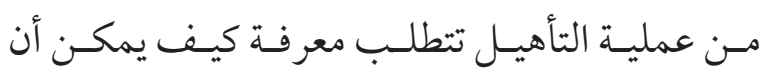

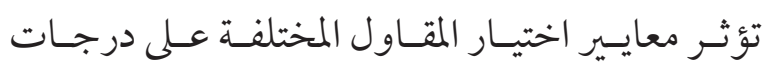
النجــاح في تحقيـق أهــاف المـشروع الرئيسـة.

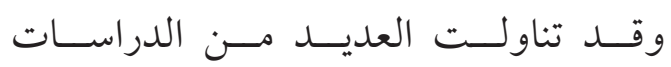

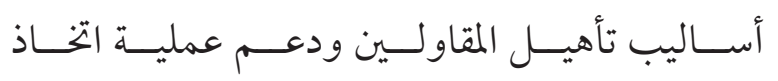

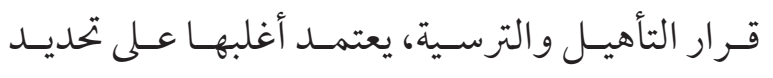

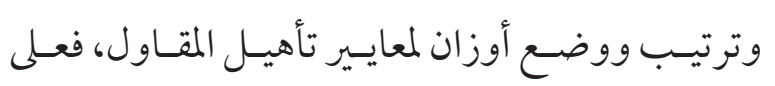

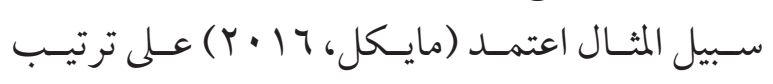

يتــم تطبيـق عنــاصر ومعايسيـر للتصنيـفن

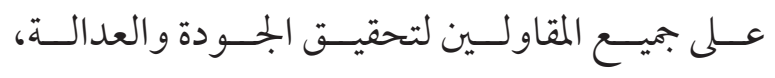

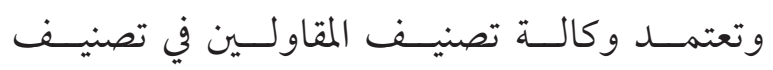
المقـــاول عـلى ثلاثــة جوانـب أساسـية: الأول: مـالي يتضمسن أربعـة معايسير رئيسـة وعـدد ( • (1) معايسير

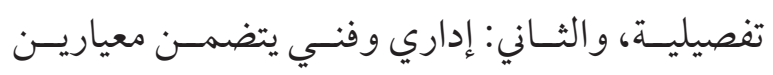
رئيسـين وعـدد (V) معايــير تفصيليـة، و الثالــثـ:

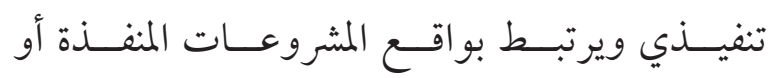

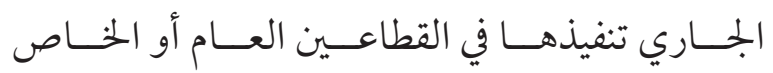

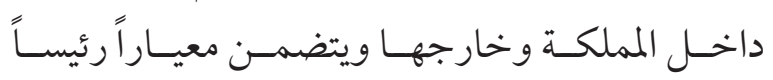

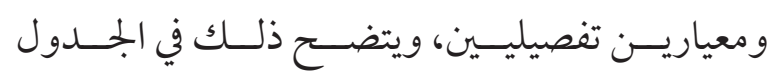

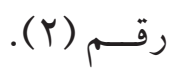

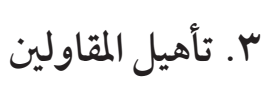

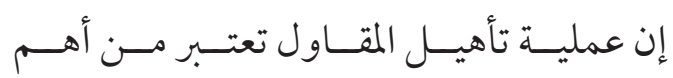

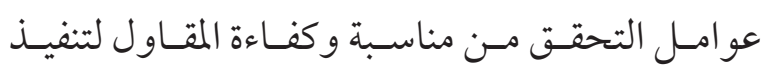

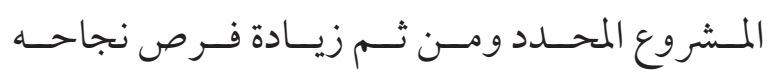
جدول رقم (Y). يوضح معاير تصنيف المقاولين

\begin{tabular}{|c|c|c|c|c|c|c|c|c|c|c|c|c|c|c|c|c|c|c|c|c|}
\hline \multicolumn{21}{|c|}{ معايير تصنيف المقاولين طبقاً لموقع وكالة تصنيف المقاولين } \\
\hline \multirow{2}{*}{\multicolumn{2}{|c|}{ المعاينة }} & \multicolumn{8}{|c|}{ الجانب الفني والإداري } & \multicolumn{10}{|c|}{ الجانب الملالي } & \multirow{2}{*}{ المئيسية } \\
\hline & & & & وعات & & & & 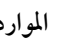 & & 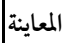 & & المالية & النسـ & & & خ & 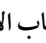 & & الميزانية & \\
\hline 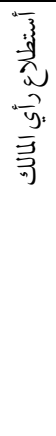 & $\frac{3}{\frac{3}{3}}$ & 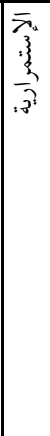 & 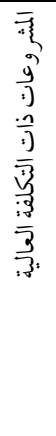 & $\begin{array}{c}\frac{3}{3} \\
\frac{3}{y} \\
\frac{1}{3} \\
\frac{1}{3} \\
\frac{3}{3} \\
y\end{array}$ & $\begin{array}{l}\bar{y} \\
\frac{1}{3} \\
\overline{3} \\
y \\
y\end{array}$ & 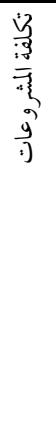 & $\begin{array}{l}\overline{\overline{3}} \\
\frac{3}{3} \\
\frac{3}{3} \\
\overline{3} \\
\overline{3} \\
\overline{3}\end{array}$ & 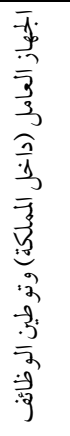 & 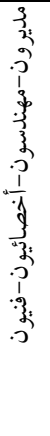 & 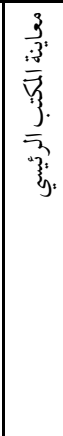 & $\frac{3}{3}$ & \begin{tabular}{|c|}
3 \\
3 \\
3 \\
3 \\
3 \\
3 \\
3
\end{tabular} & $\frac{3}{3}$ & ?. & 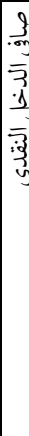 & & $\frac{\frac{3}{3}}{\frac{3}{3}}$ & $\begin{array}{l}\frac{y}{3} \\
\frac{3}{3} \\
\frac{\bar{z}_{3}}{2} \\
\frac{2}{3}\end{array}$ & 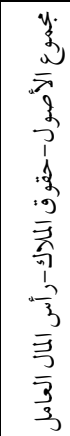 & المعايير \\
\hline
\end{tabular}

(المصدر: لائحة نظام تصنيف المقاولين من موقع الو كالة مع التصرف من قبل الباحث) 
المميـزة للمسشروع وإمكانيـة تعديلـه بسـهولة لتبنـي شروط محـددة للمسشروع المقـترح ودعـم قـرار اختيار

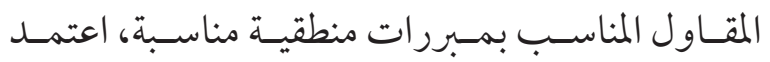

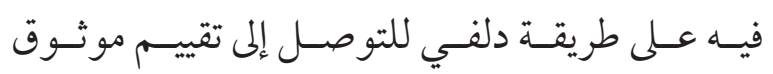

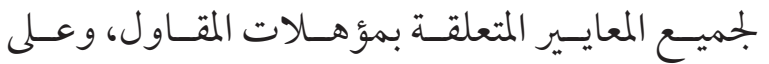

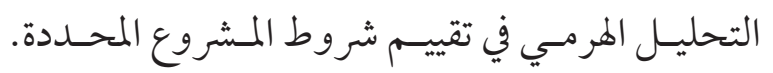

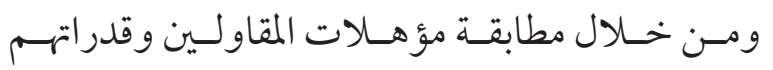

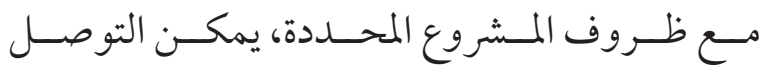
إلى قائمسـة خختـصرة مــن المقاولــين المؤهلـين لاختيــار

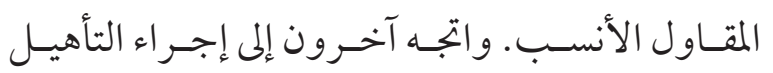
للمقاولـين مسن خـالال المنصـات الإلكترونيـة (بارنز،

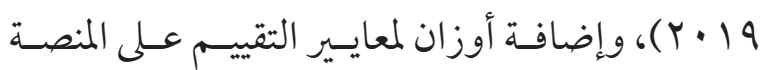
لتحقيـق الشـفافية في الإجــر اءات (أميليـا، 1 | • ب). وتختلــف معايـير تأهيــل المقاولــين مــن مـشروع إلى مسشروع، ومــن دولـة إلى أخــرى وفقــاً

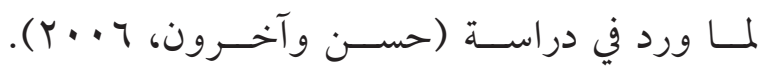
ولتحديـد المعايـير المناسـبة لمنطقــة أو بلــ معـين يجـبـ

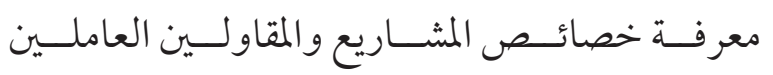

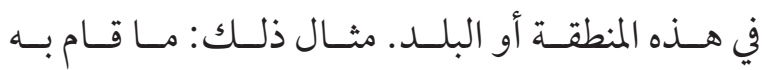

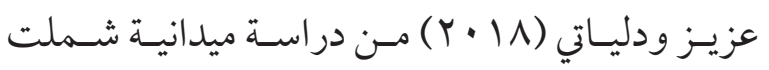

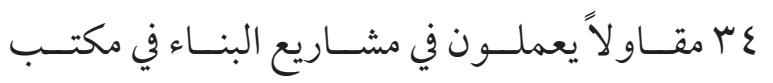

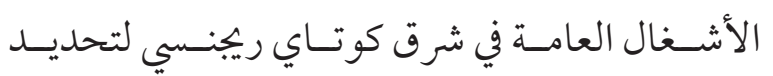

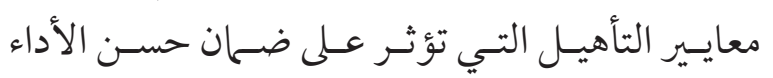

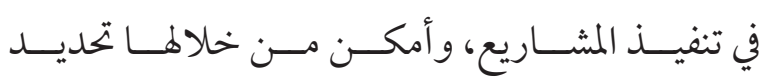

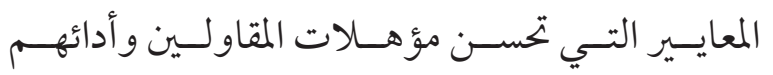

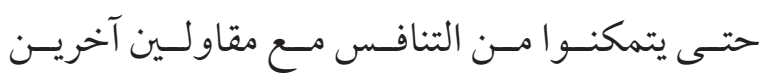

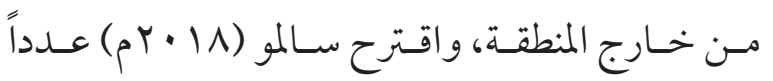

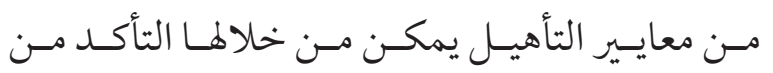

متعـدد الســات ك لتحديــد معايـير الترجيـح وتطبيـق

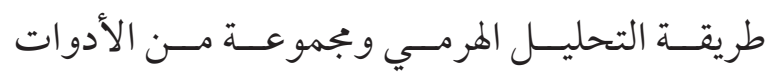

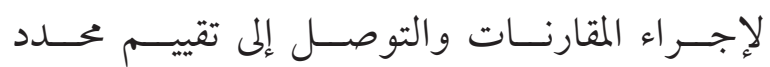
لـكل مقــاول يتـم عـلى أساسـه تحديـــ الأفضليـة في

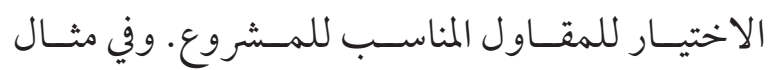

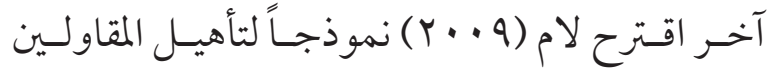
في تنفيـــ المشـــاريع المعقــــة وذات القيمـــة العاليــة يسـتهدف تحقيـق أفضـل قيمـة مـن خـالال ضمانـات

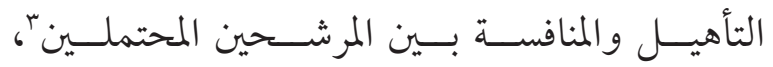

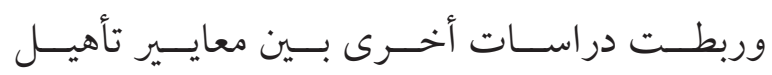
المقــاول وخصائُص وســات المـشروع الـــي يتــم

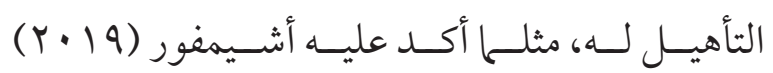

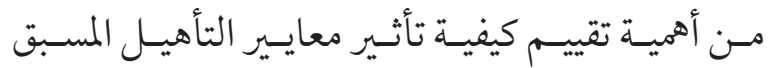

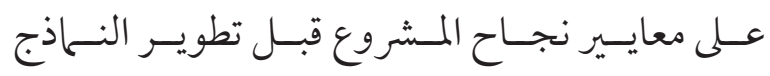

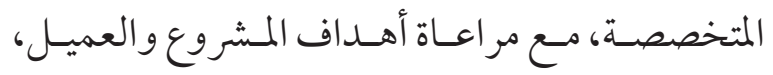

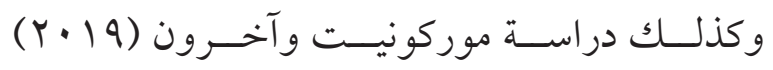
التـي اختصــت بتحديــد معايـيـر متخصصـة لمقــاولي

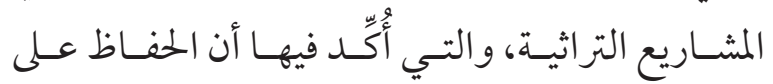

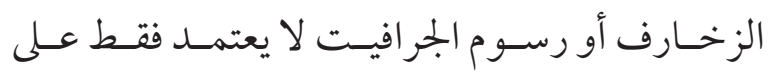
المعرفـة التاريخيـة والمعلماريسة والدراســات ومشــاريع

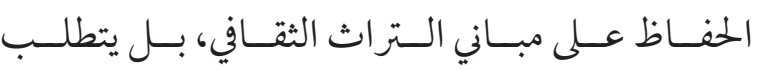

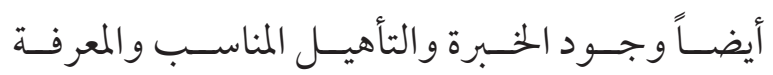

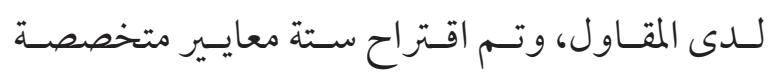

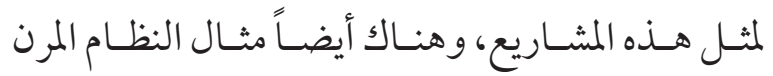

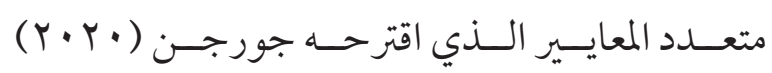

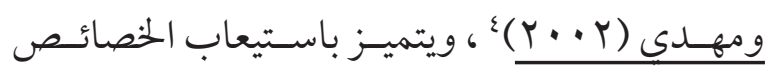

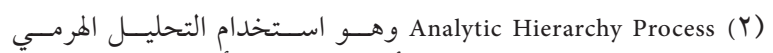

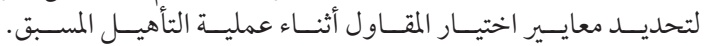
Support Vector Machine (Y)

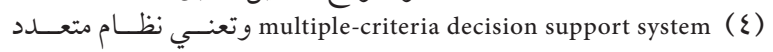

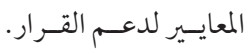


وإرجونسول، (1) • (Y) الـذي توصـل إلى نمـوذج مماثل

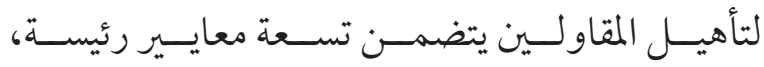

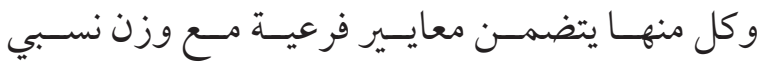

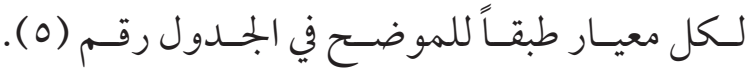

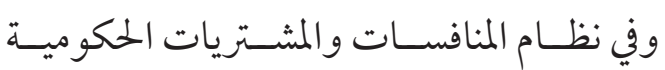

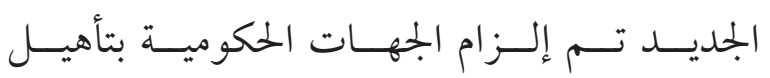

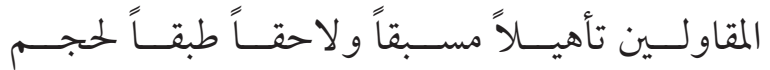

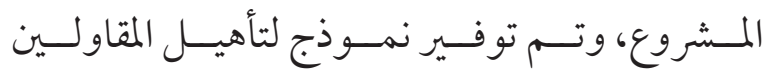

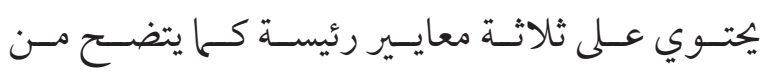

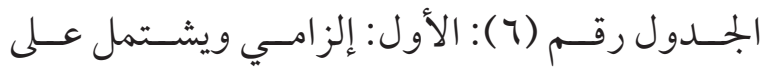

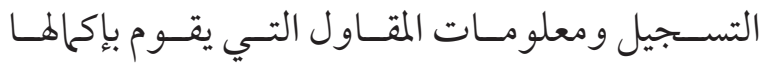

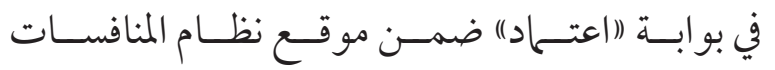

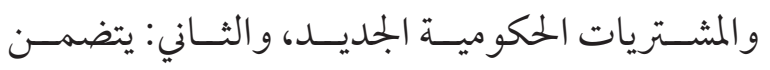
بيانـات القــدرات الفنيــة والإداريــة للمقــــاول ويحتـوي على سـبعة معايـير تفصيليـة بعضهـا ينقسـم
خـبرة المقاولـين وســمتتهم وفريـق الإدارة والقــدرة

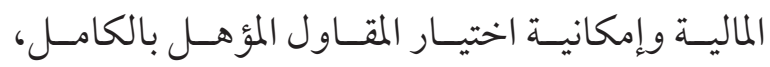
مـن خــال عمليـة تقيـــم منهجيـة وتقييــم شـامل

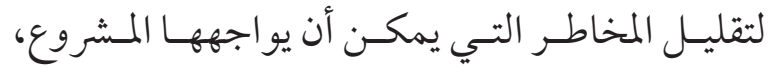

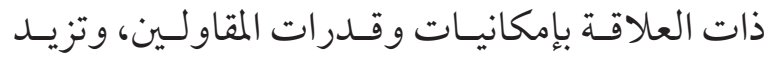

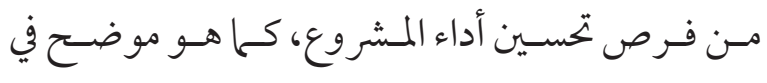

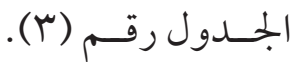
وكخطـوة إضافيـة عسلى معايـيـر التأهيـل اقترح

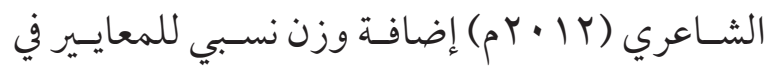

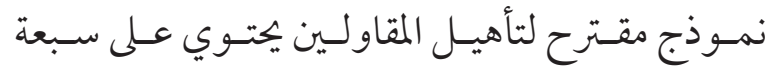

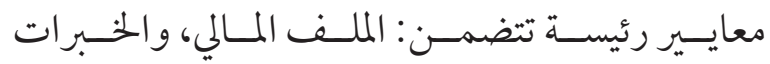

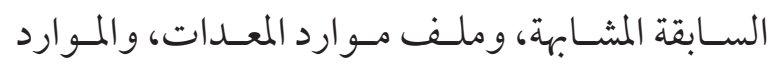
البشريـة، والملـف الفني، وملف التخطيط و المتابعة،

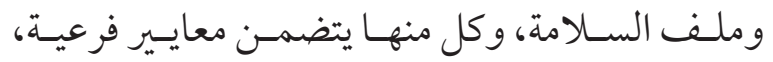

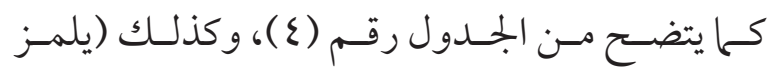

$$
\text { جدول رقم (r). يوضح أحد نماذج تأهيل وتقييم المقاولين }
$$

\begin{tabular}{|c|c|c|c|c|c|c|c|c|c|c|c|c|c|c|c|c|c|c|c|c|c|c|}
\hline \multicolumn{23}{|c|}{ معايير تقييم المقاولين في مشاريع الإسكان في نيروبي- كينيا طبقاً لدراسة (سالمو، 2018) } \\
\hline \multicolumn{5}{|c|}{ 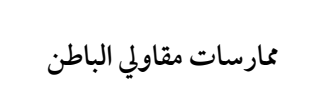 } & \multicolumn{5}{|c|}{ 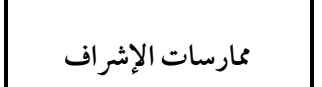 } & \multicolumn{6}{|c|}{ 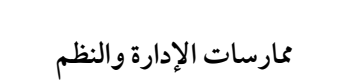 } & \multicolumn{6}{|c|}{ 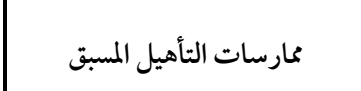 } & المعايير \\
\hline 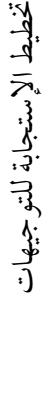 & 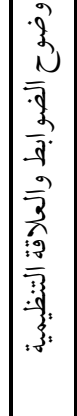 & 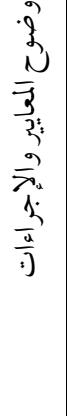 & 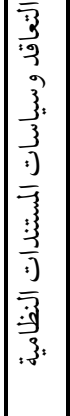 & $\begin{array}{l}3 \\
3 \\
3 \\
3 \\
3 \\
3 \\
3\end{array}$ & 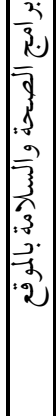 & 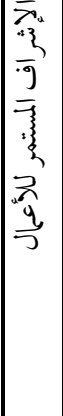 & 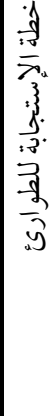 & 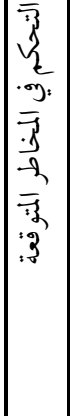 & 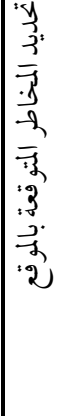 & 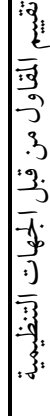 & . & 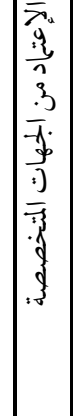 & $\begin{array}{l}3: \\
3 \\
.3 \\
.3 \\
\overline{3} \\
\overline{3}\end{array}$ & $\begin{array}{l}\frac{5}{2} \\
\frac{10}{3} \\
\frac{3}{3} \\
.3\end{array}$ & $\mid \begin{array}{c}\frac{3}{2} \\
\frac{.0}{-1} \\
\frac{1}{2} \\
\therefore 0\end{array}$ & 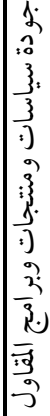 & 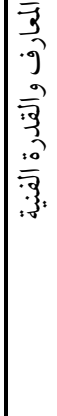 & $\frac{3}{\frac{3}{3}}$ & 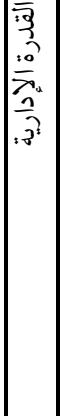 & 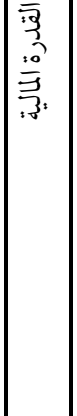 & 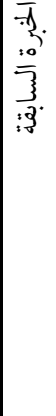 & المعايير \\
\hline
\end{tabular}

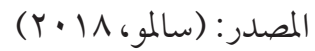




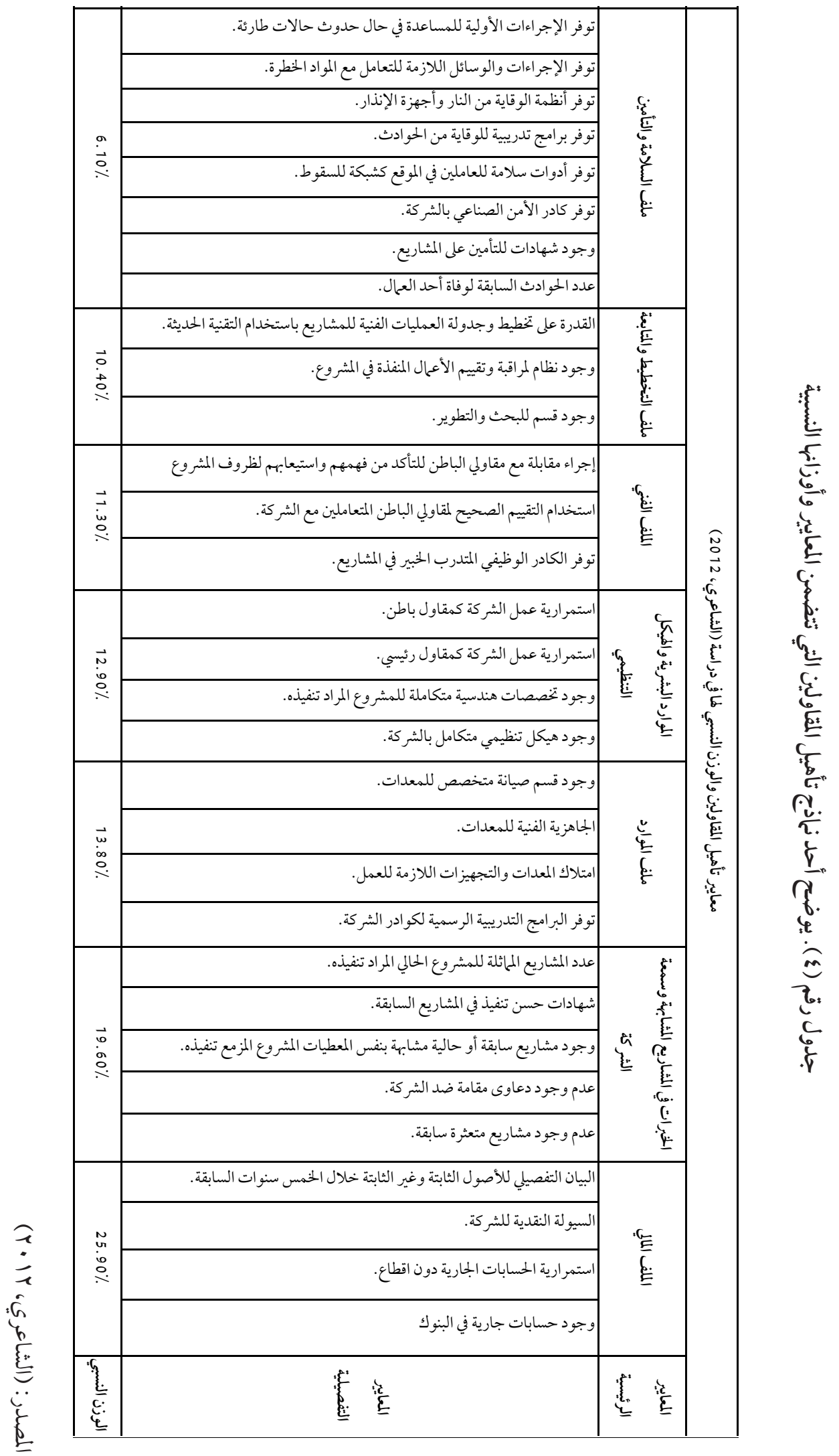


جدول رقم (ه) . يوضح معايير تأهيل المقاولين ووزنها النسبي

\begin{tabular}{|c|c|c|c|c|c|c|c|c|c|c|c|c|c|c|c|c|c|c|}
\hline \multicolumn{19}{|c|}{ معايير تأهيل المقاولين والوزن النسبي لها في دراسة (يلمز وإرجونول، 2011) } \\
\hline \multirow[b]{2}{*}{ 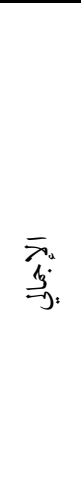 } & إلبيئة & \multicolumn{2}{|c|}{ الصحة } & \multicolumn{2}{|c|}{ إلجودة } & \multicolumn{2}{|c|}{ إدارة } & \multicolumn{2}{|c|}{ الخباتقة } & \multicolumn{2}{|c|}{ مستوى الأداء في } & \multicolumn{2}{|c|}{ موارد } & الموارد & \multicolumn{3}{|c|}{ شركة المقاو لات } & المعايير \\
\hline & 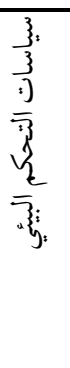 & 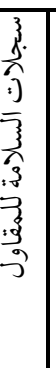 & 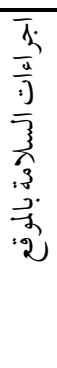 & 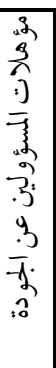 & 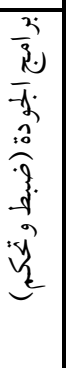 & 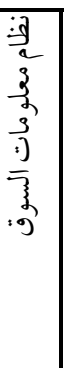 & 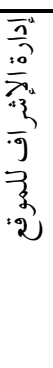 & 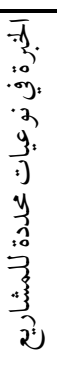 & 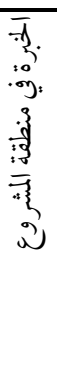 & 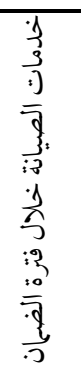 & 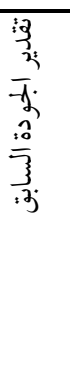 & 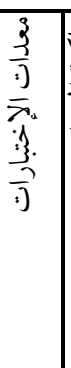 & $\frac{3}{\frac{3}{3}}$ & 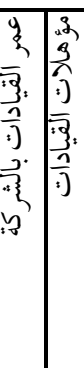 & 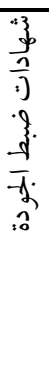 & 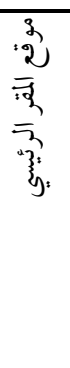 & 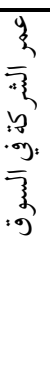 & المعصيلية \\
\hline 30 & 2 & 1 & 2 & 2 & 2 & 1 & 1 & 2 & 2 & 2 & 2 & 1 & 1 & 1 & 2 & 2 & 2 & المعيار \\
\hline $100 \%$ & $6.7 \%$ & 10. & $.0 \%$ & & $.3 \%$ & 6.7 & & & & & & $6.7^{\circ}$ & & $10.0 \%$ & & 20.0 & & الوزن \\
\hline
\end{tabular}

المصدر: (يلمز وإرجونول، 11)

البنديــن السـابقين مــن دراســات ونــاذج ومعايـير

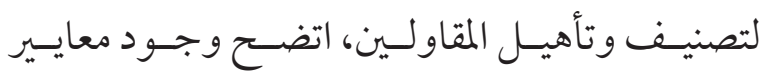

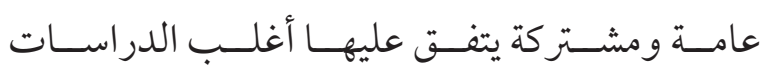

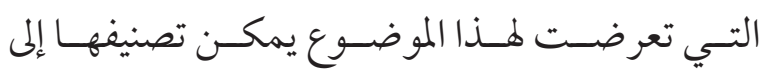
فئـات اختلفـت نـلـاذج التأهيـل في أسـلوب تجميعهـا، واتفقـت عـلى المعايـير الرئيسـة مثـل : القـدر ات المالية

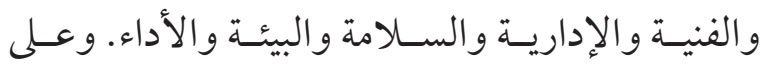

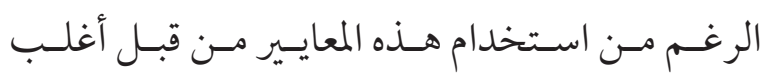

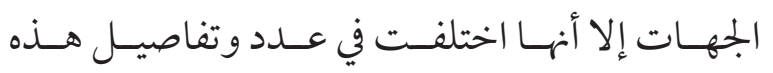

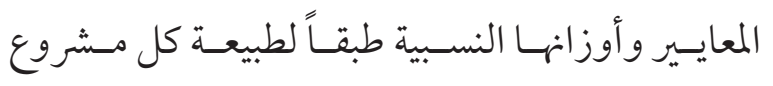

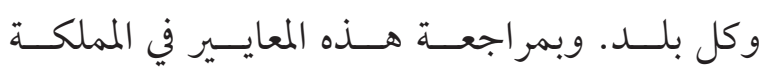

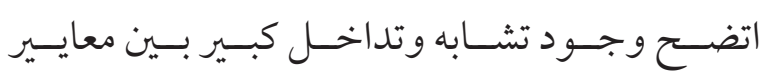
تصنيـف المقاولـين في النظـام المطـور المتوقـع إصــاره

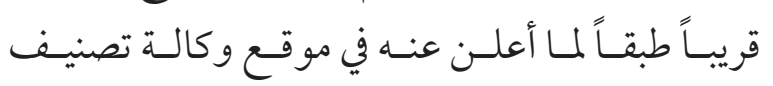

إلى معايســر فرعيـة، و الثالــث : يتضمـــن القــدرات

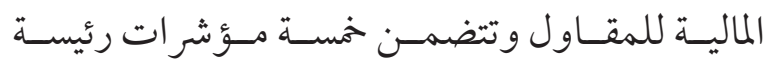
لتحديــد القـدرات الماليـة للمقــاول. وتـم في النموذج تحديــد أوزان نســبية فرعيـة للبنــود المشــتملة في كل معيـار رئيسـ مـع الفصـل التـام بــين التقييــم الفنـي

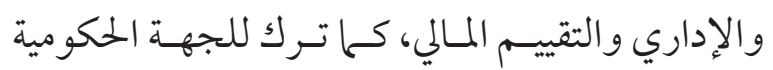

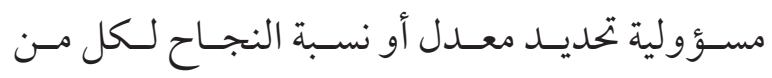

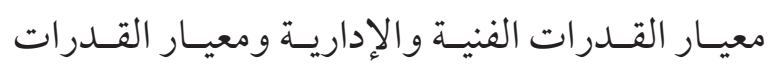

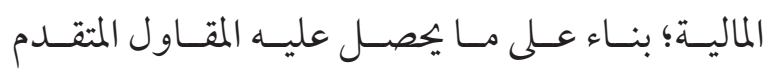

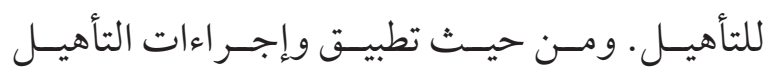

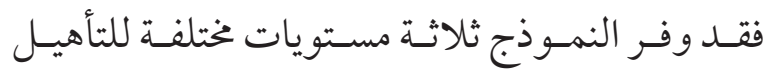

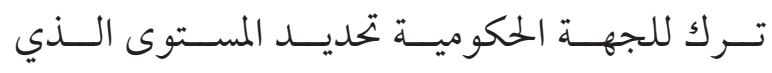
يتناسـب مــع طبيعـة المـشروع وحجمــه وقيمتـهـ. مـن واقـع مــا تــم مراجعتــه واسـتعر اضه في 


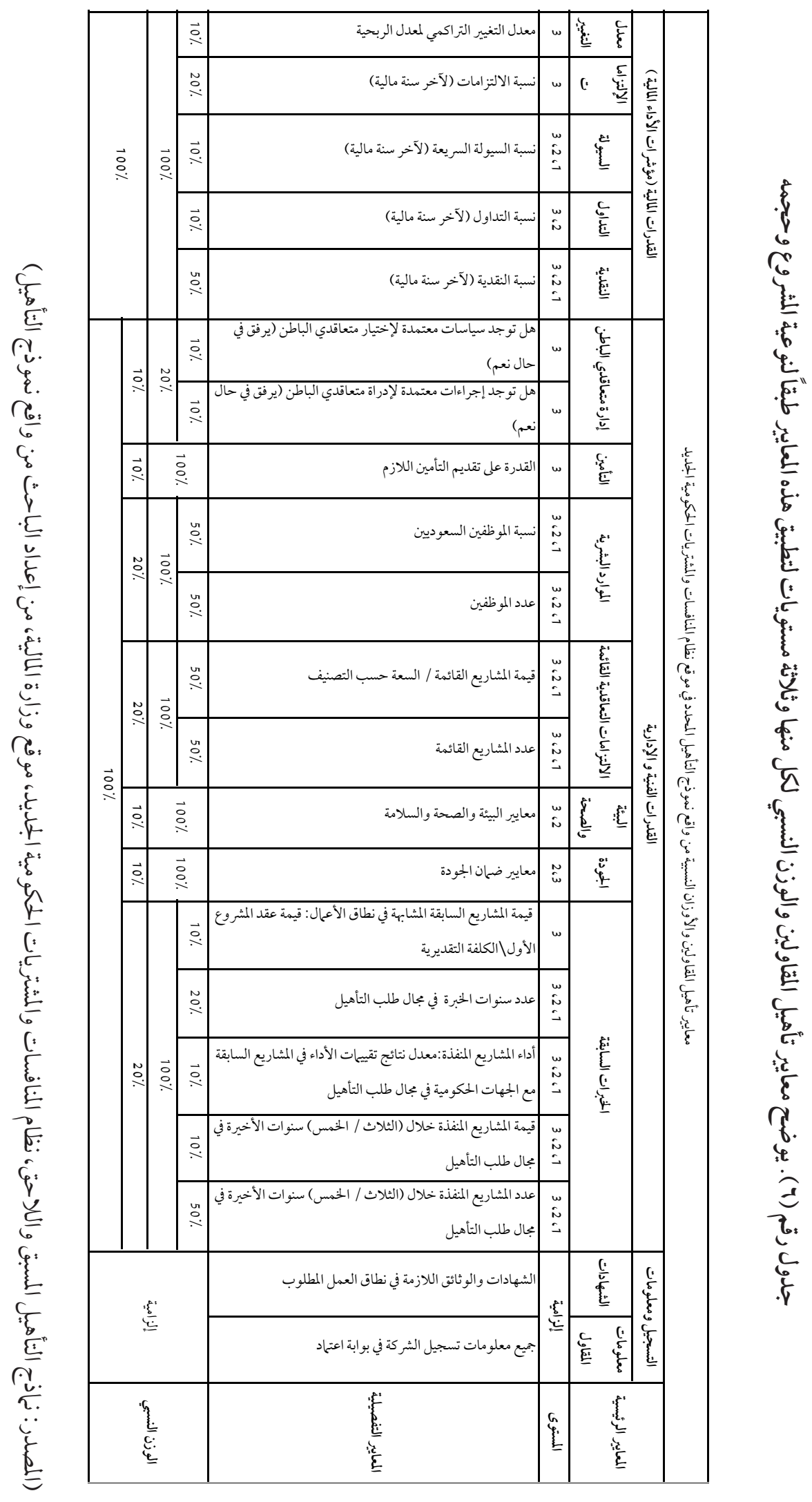


وتأهيـل المقاولـين، وأمكــن في نهايسـة هــــه المرحلـة

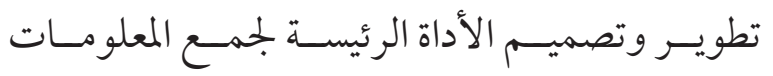

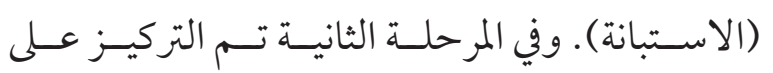

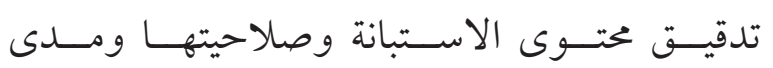

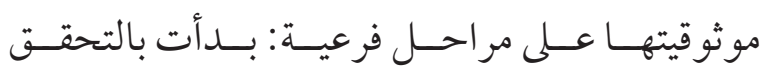

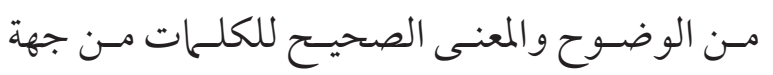

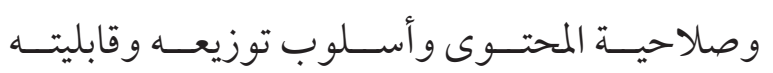

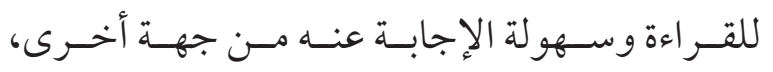

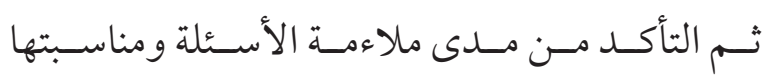

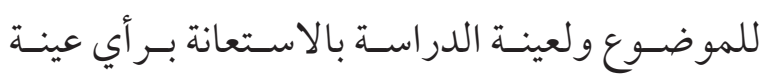

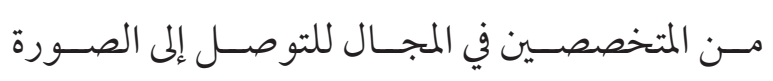

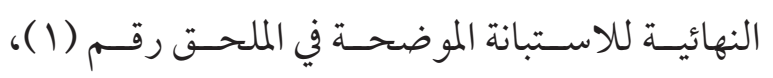

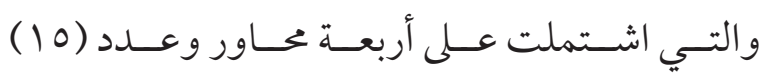

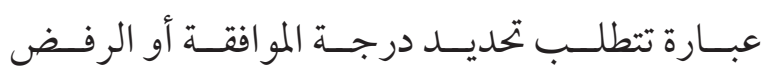
عليهـا (مقيـاس ليكـرت الخـاسي)، إضافة إلى سـؤال

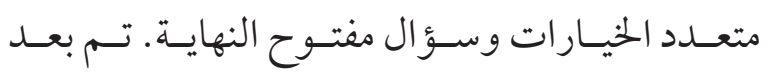
ذلـك التحقـق مــن موثوقيسة الاسـتبانة مسن خــالال

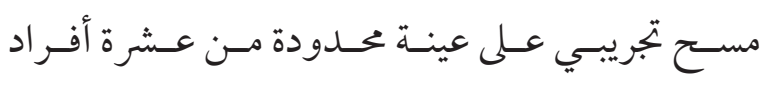

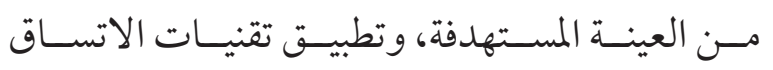

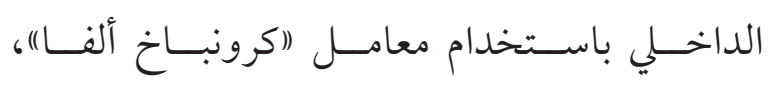

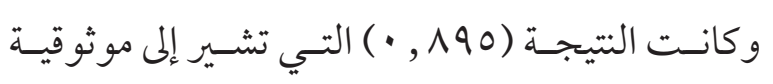

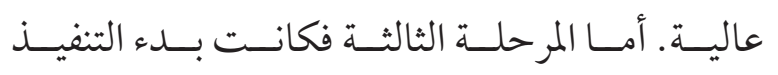

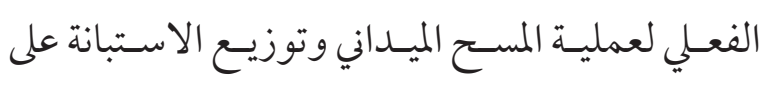

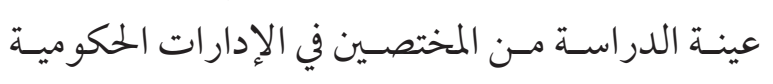

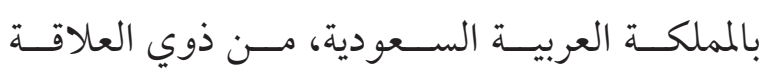

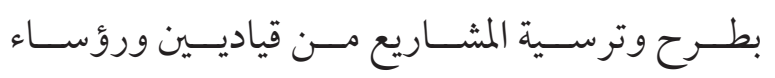

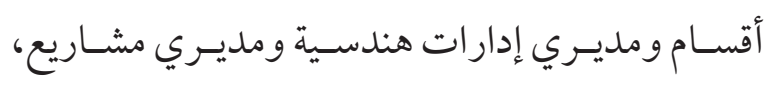

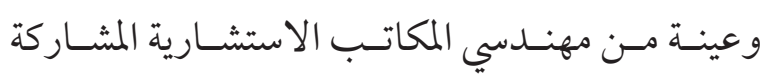

المقاولــين؛ ومعايـيـر تأهيـل المقاولـين المححــددة في

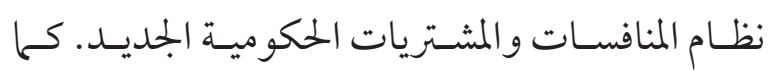

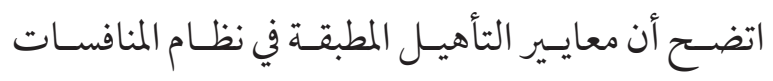

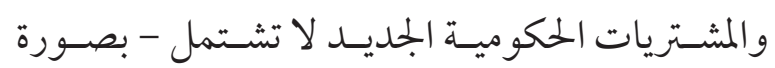

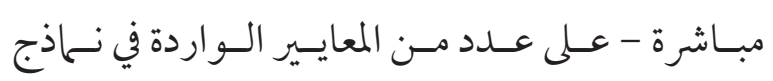

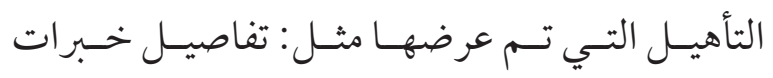

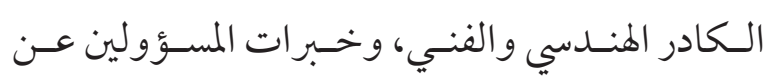

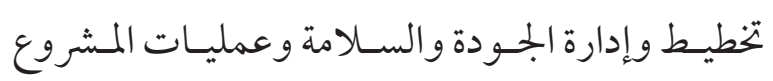

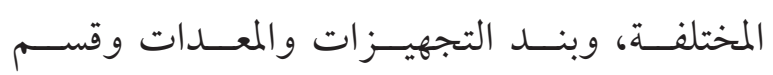

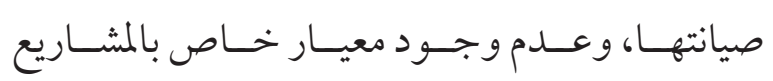

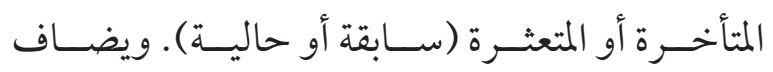

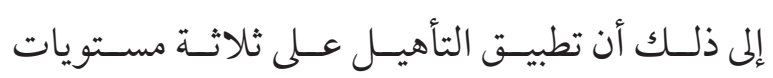

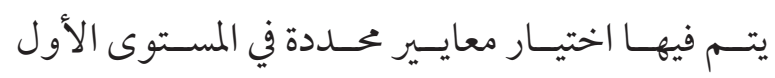
و الثـاني؛ لو حـظ فيـه افتقـاد المســتوى الأول لمعايسير

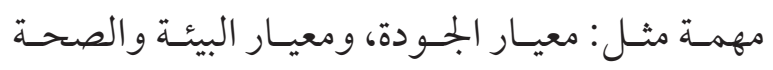
والسـلامة.

\section{ع ـ واقع تصنيف وتأهيل المقاولين بالمملكة العربية

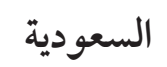

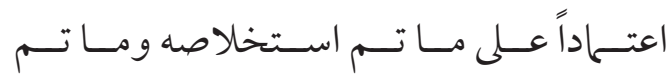

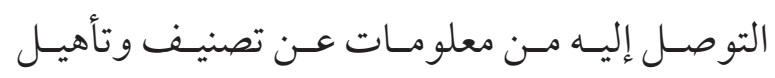
المقاولـين خـالال المر اجعـات الأدبيـة في الجزء السـابق تصني

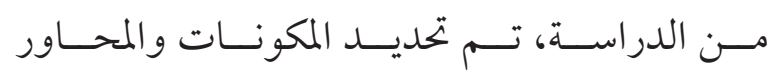

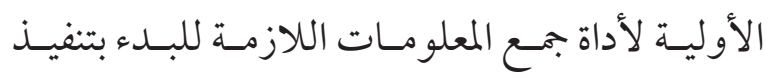

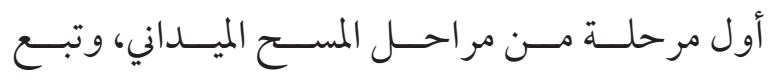

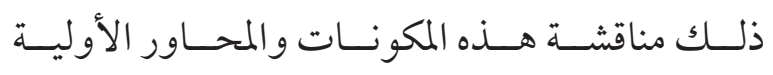

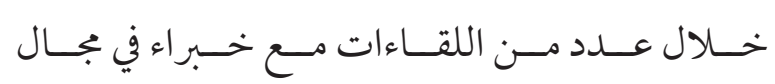

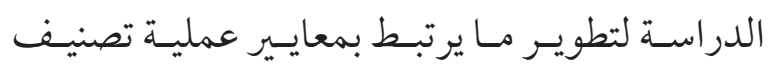




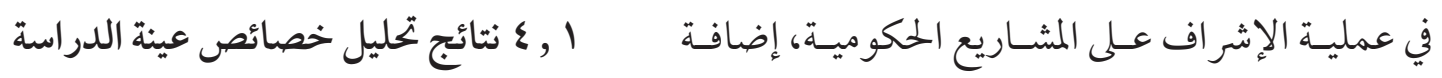

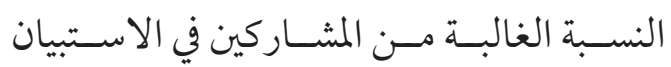

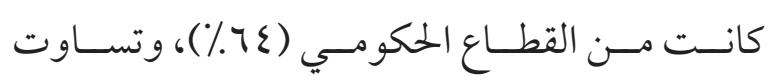

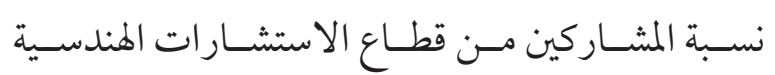

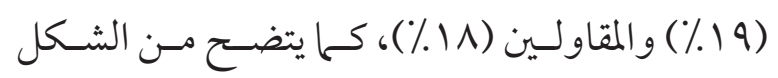

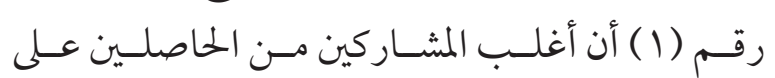

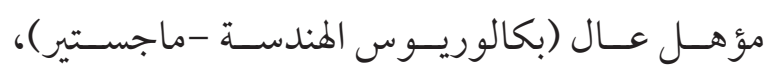

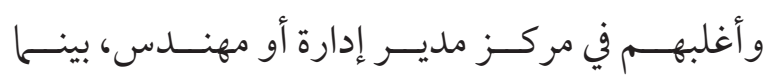

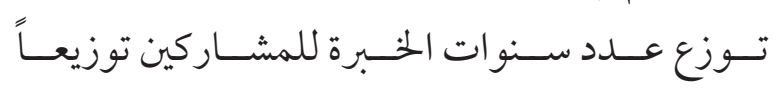
متو افقــاً مــع منحنسى التوزيــع الطبيعـي.

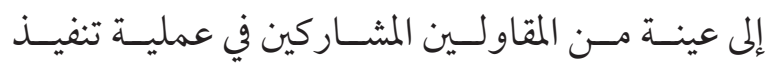

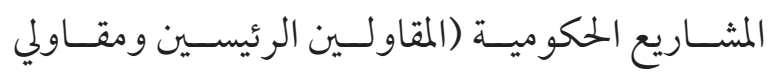
الباطـن)، ومتابعـة وصوهـا و إعـادة استـامها تمهيــاً لتفريـغ وتحليـل البيانـات واستختلاص النتائـج. وقد وقد

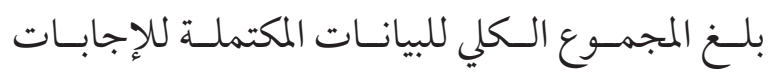

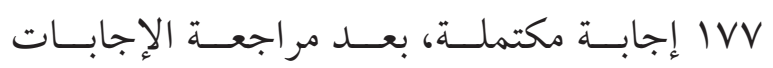

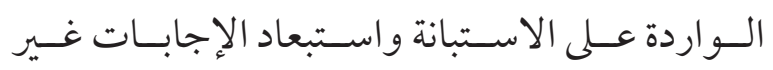

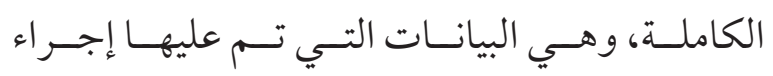

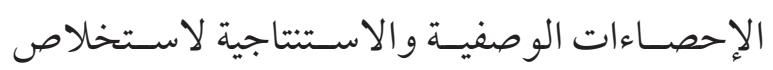

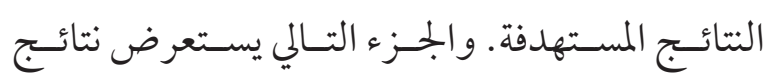
هـذا المســـح الميـداني.

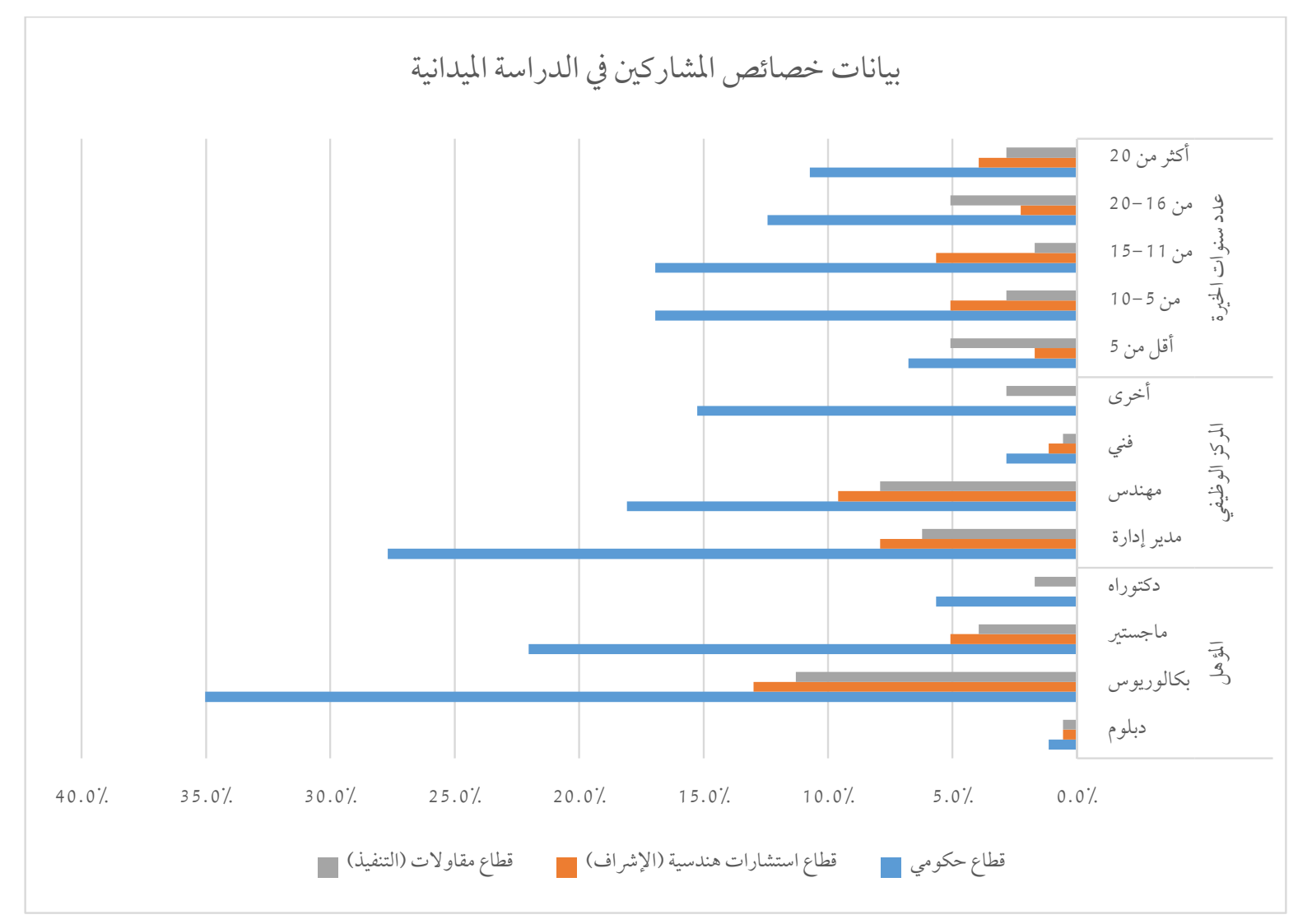

الشكل رقم (1) . تحليل خصائص عينة الدراسة 
لمتوســط اســتجابات القطــاع الحلكومــي فكانــت

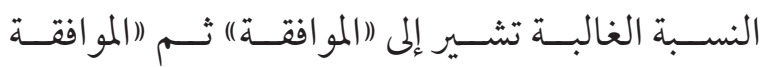

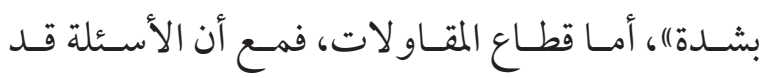

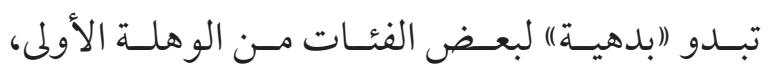

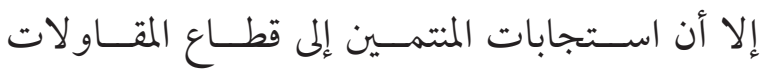
اختلفــت عــن اسـتجابات فئــة الاستشـاريين

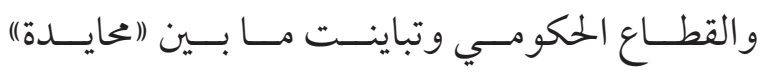

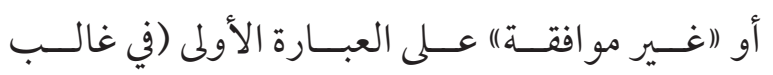

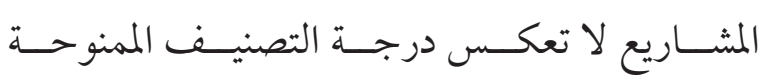

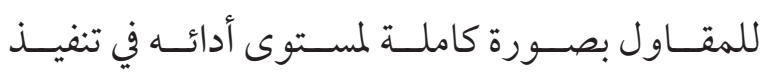

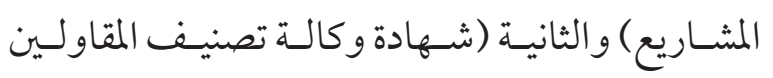

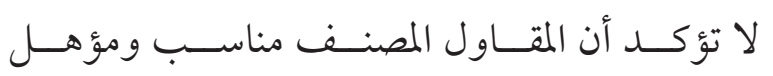

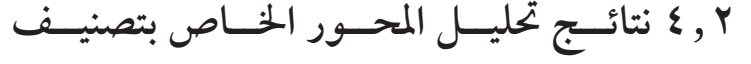
المقاولـين احتـوى هــذا المحـــور عـلى ثـلاث عبــار ات

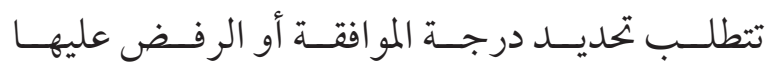

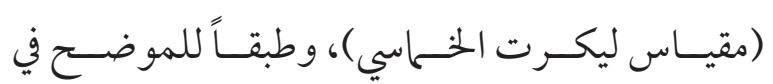
الشـكل رقــم (Y) فتــــ انفــردت اسـتجابات قطــاع

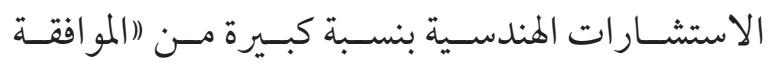

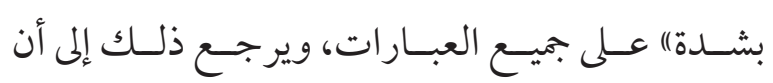

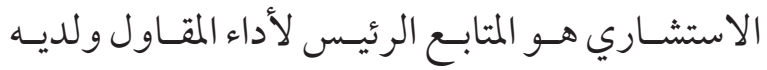

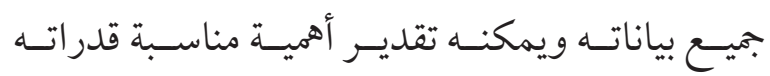
لمتطلبـات المششروع بنسـبة موثوقيـة عاليـة. وبالنسـبة نتائج تساؤلات محور تصنيف المقاولين

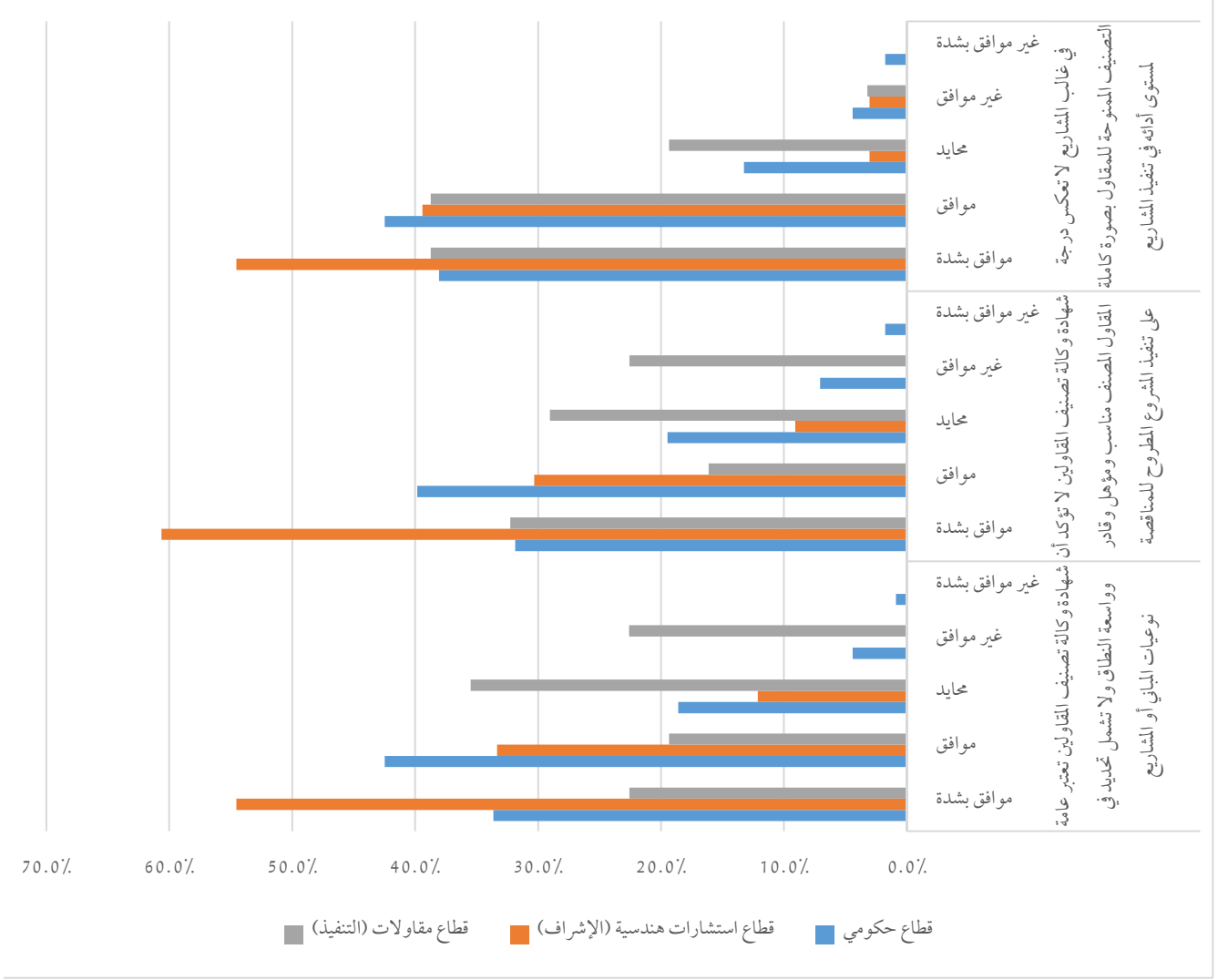

الشكل رقم (Y). نتائج استجابات عينة الدراسة تجاه عبارات المحور الخاص بتصنيف المقاولين 


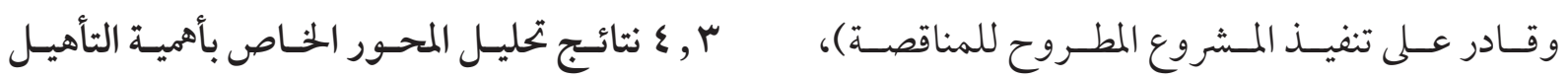

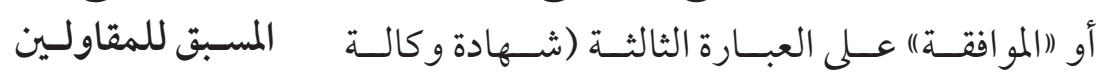
احتـوى هـــا المحـــور عـلى ثـلاث عبـارات

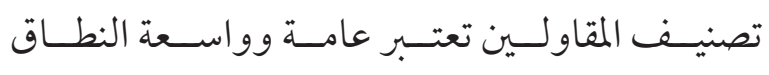

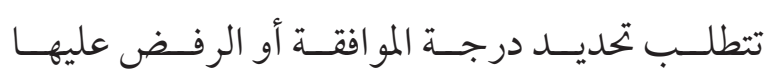

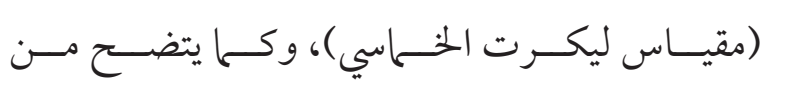

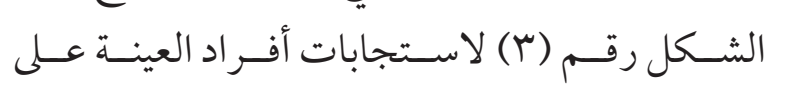

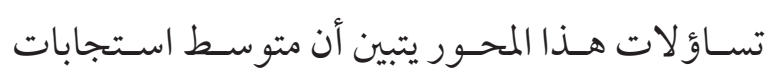

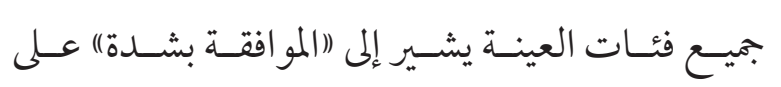

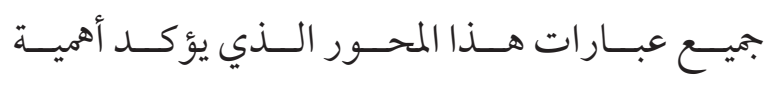

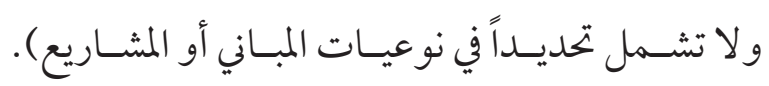

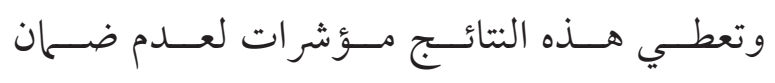

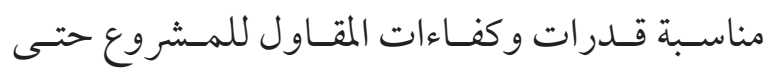

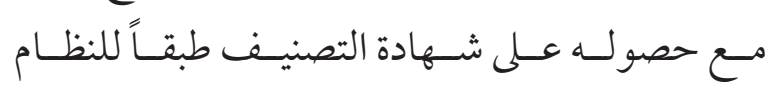

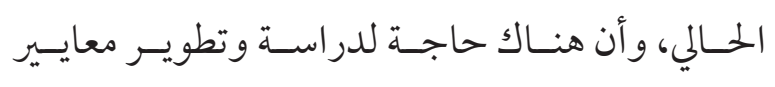

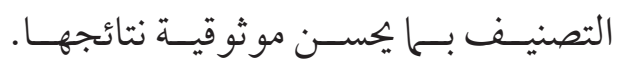

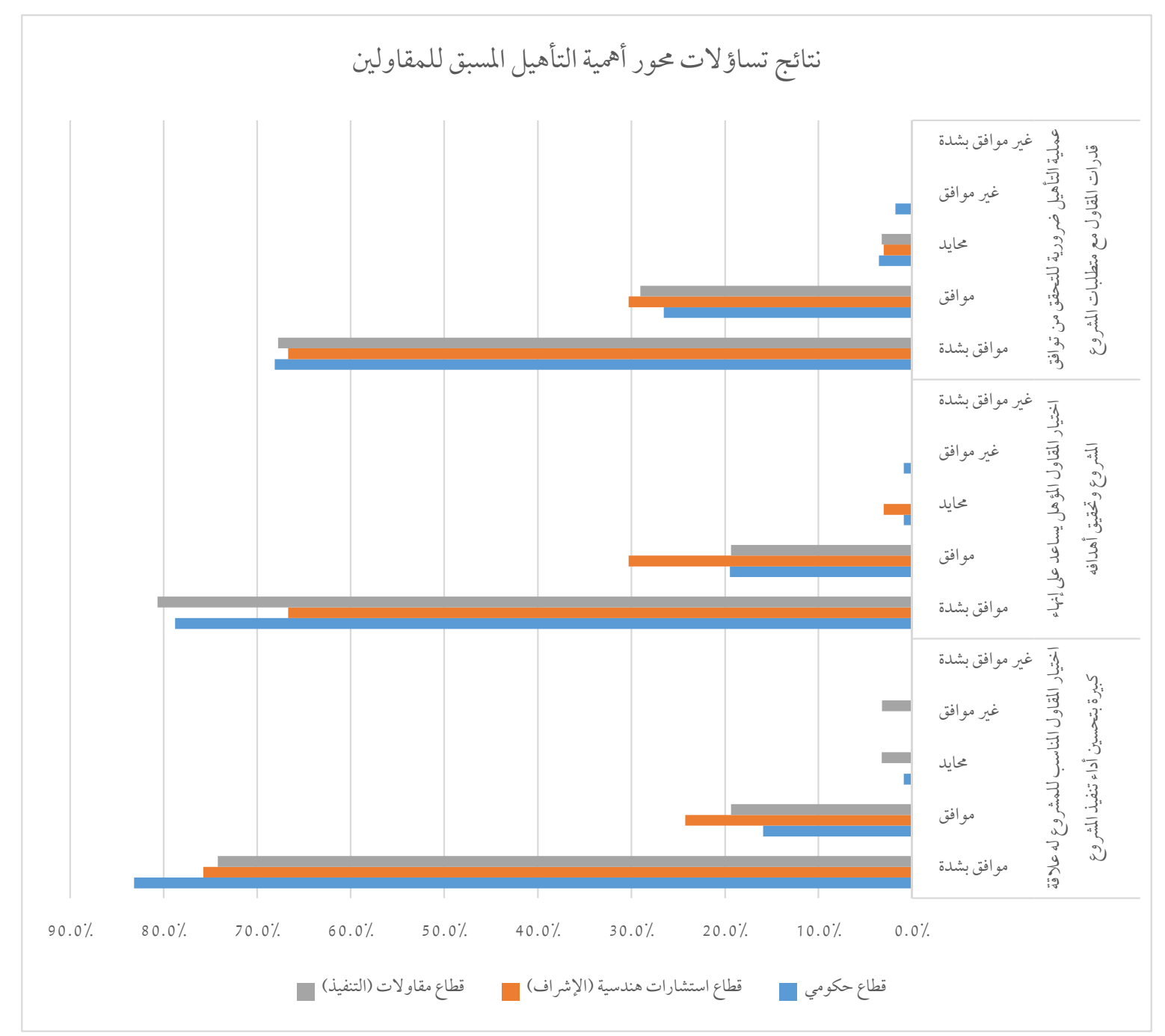

الشكل رقم (r). نتائج استجابات عينة الدراسة على التساؤلات ذات العلاقة بأهمية عملية التأهيل المسبق للمقاولين 
بهـا في عمليـة التأهيـل واقـتراح أي معايـيـر إضافيـة.

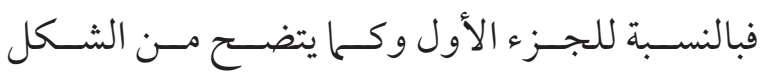

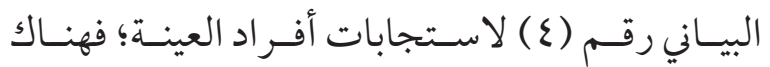

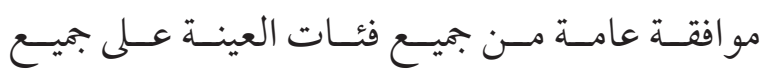

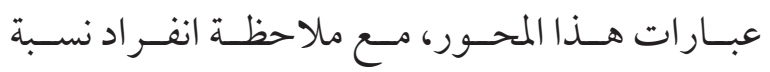

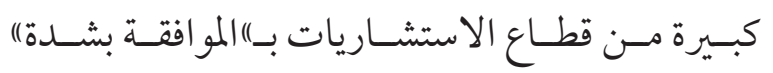

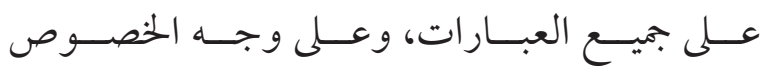

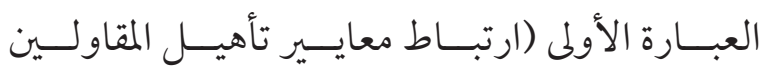

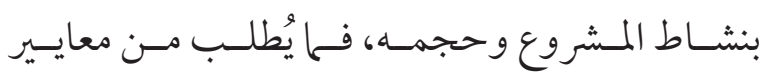

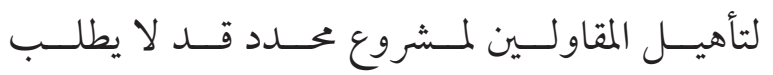

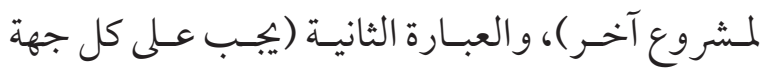

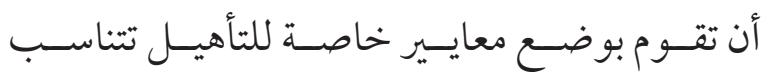

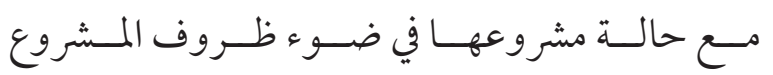

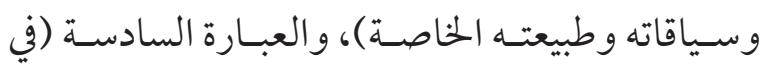

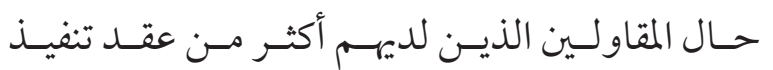

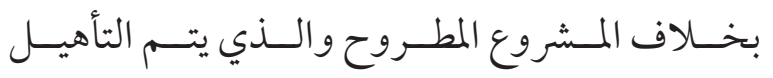

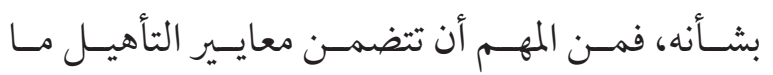

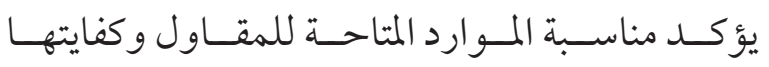

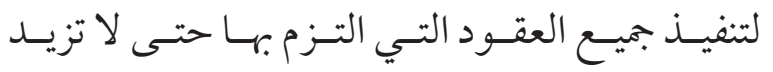

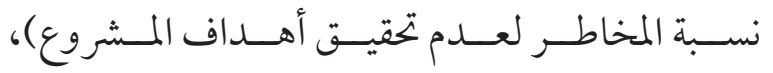

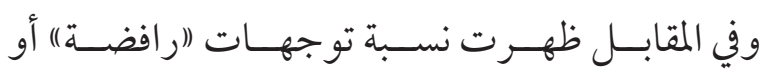

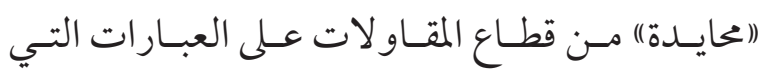

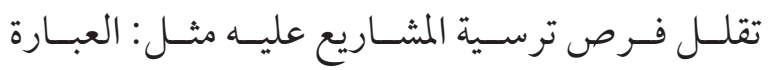

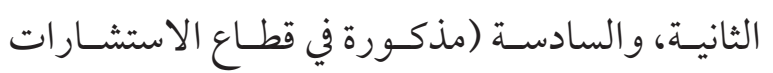

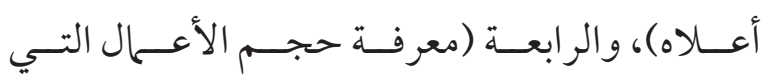

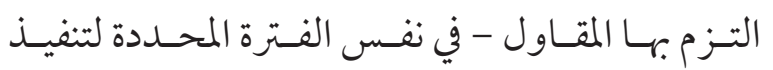
المششروع المطــروح للمنافسـة - تعتـبر أحسـ المعايسير

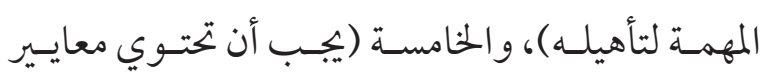

التأهيـل المسـبق للمقاولـين سـو اء مـن حيــث أهميـة

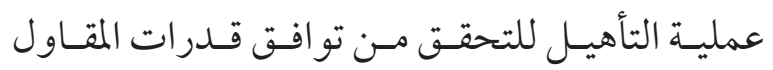

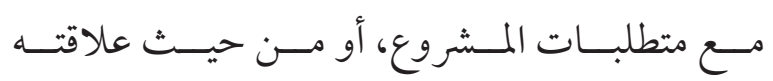

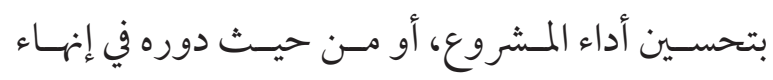
المسشروع في وقتسه وتحقيـق أهدافـه.

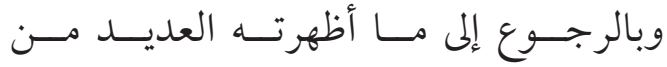

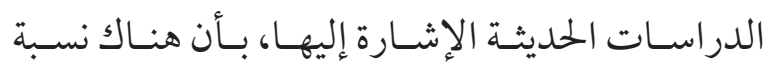

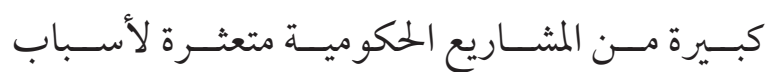
متعـددة، استحوذ ضعـف إمكانيـات المقـاول الفنيـة

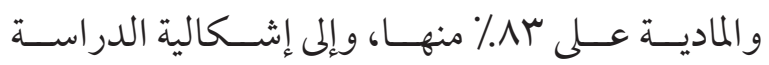

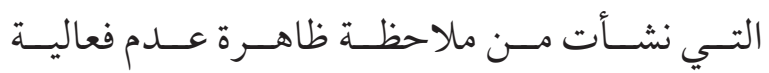

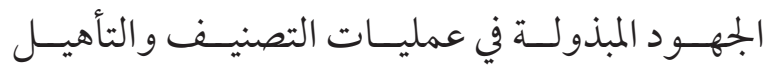

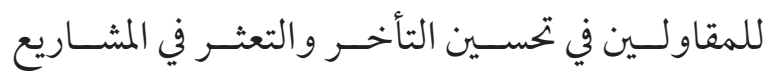

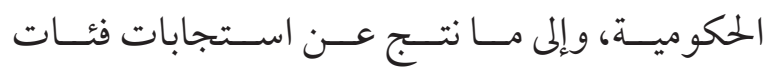

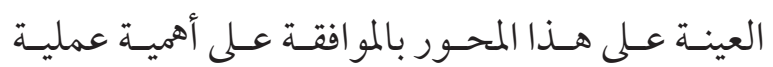

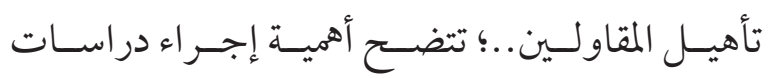
متخصصــة لتطويسر نــاذج ومعايسير التأهيـل

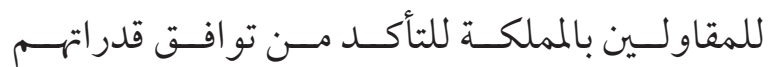

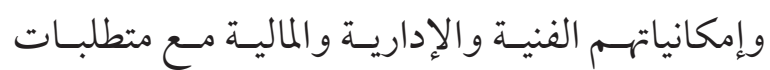

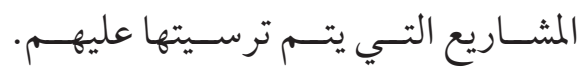

؟ , ع نتائسج تحليـل المحسور الخـاص بمعايسير تأهيـل المقاولين

احتــوى هـــا المحـــور عـلى جزأيسـن الأول:

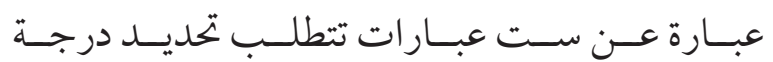

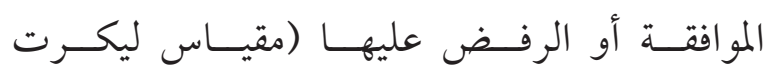

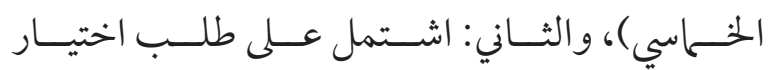

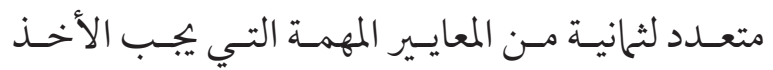




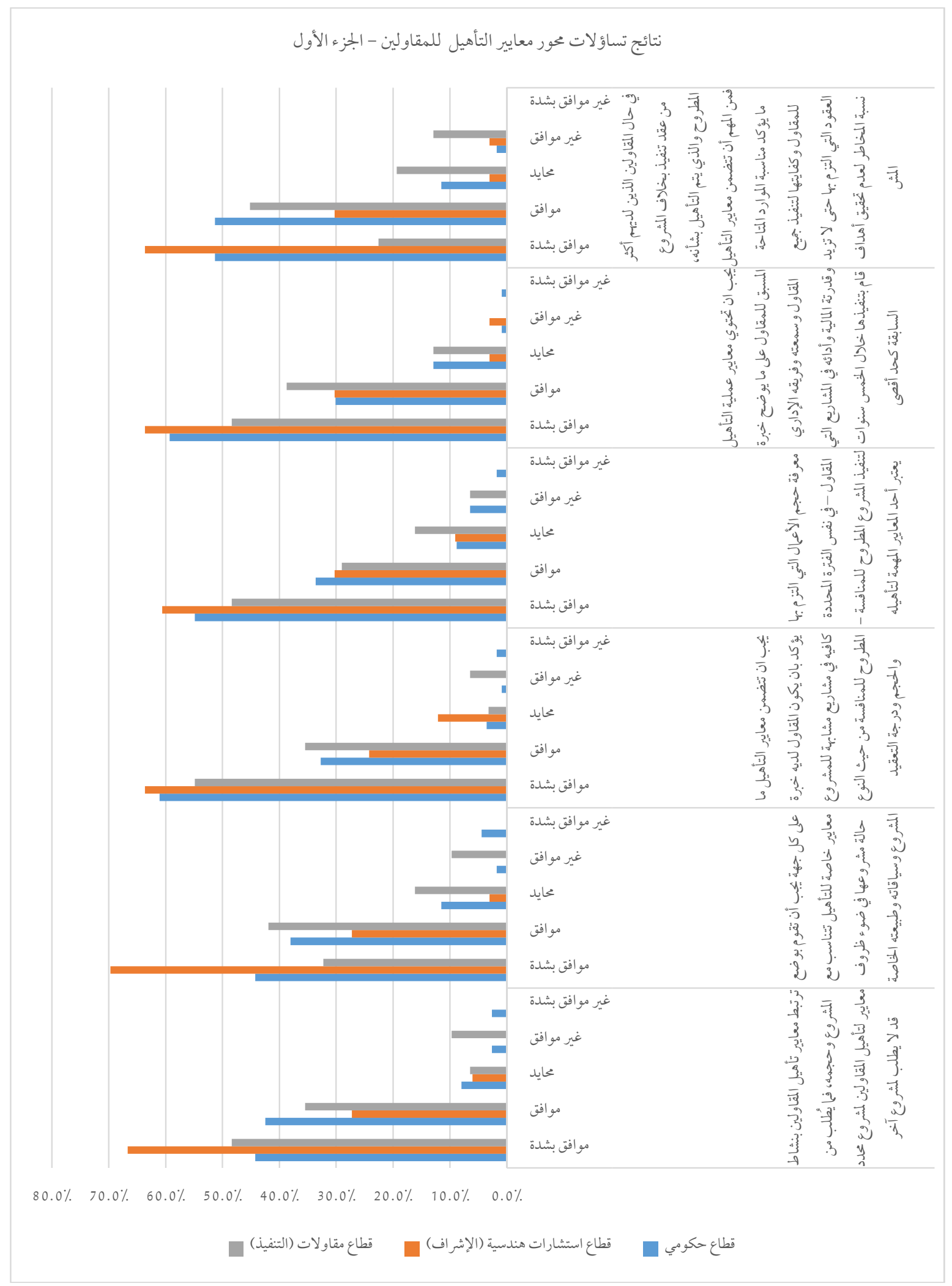

الشكل رقم (ع). نتائج استجابات عينة الدراسة على الجزء الأول من التساؤلات ذات العلاقة بمعايير التأهيل المسبق للمقاولين 


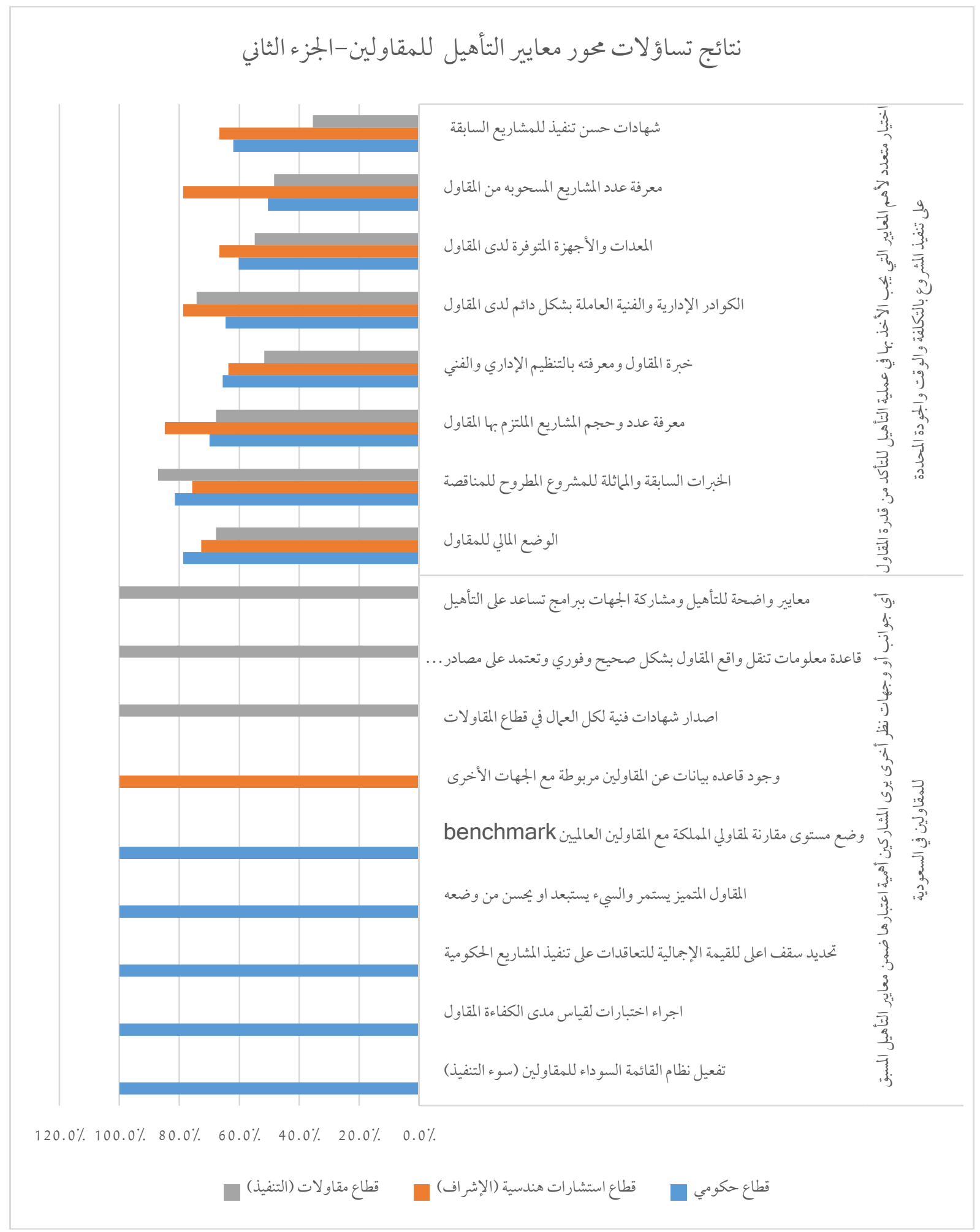

الشكل رقم (ه). نتائج استجابات عينة الدراسة على الجزء ذي التساؤلات المفتوحة ذات العلاقة بمعايير التأهيل المسبق للمقاولين 


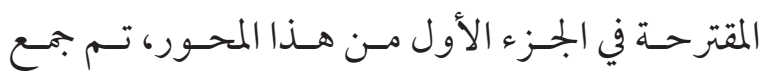

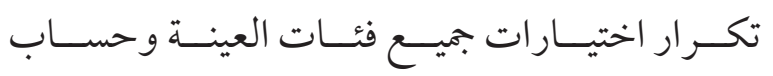

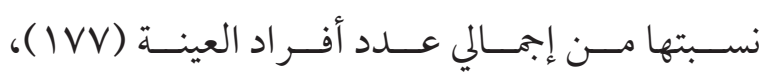

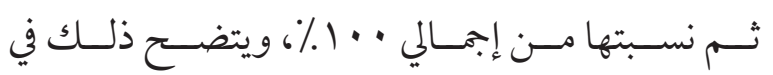

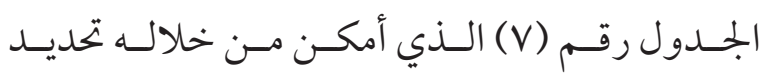

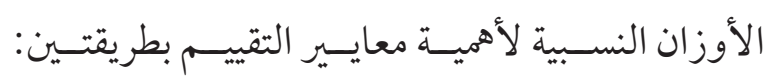

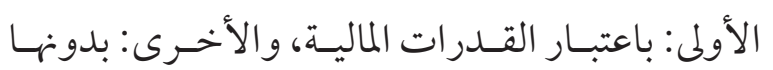

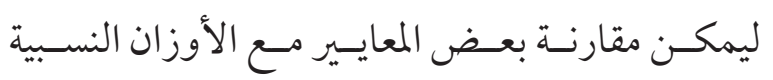

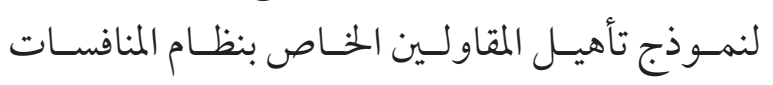

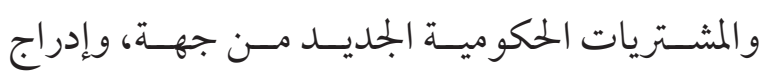

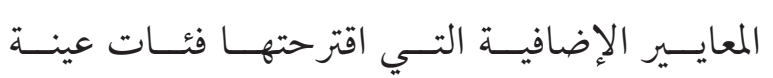

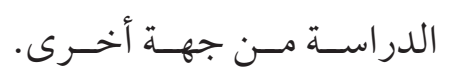

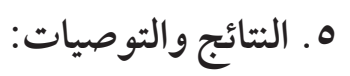

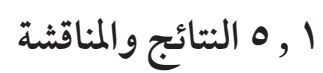

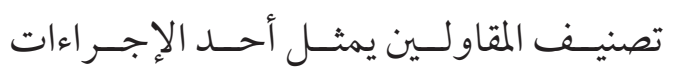

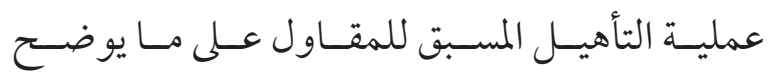

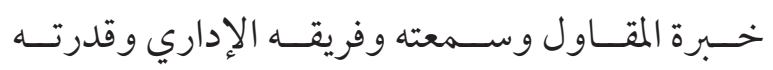
الماليــة وأدائه في المشــاريع التـي قـام بتنفيذهــا خـلال

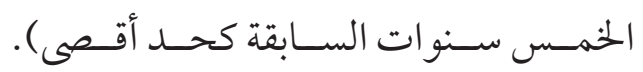

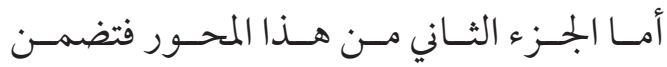

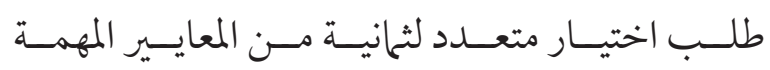

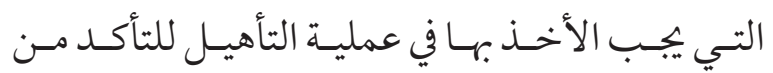

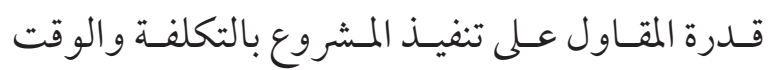

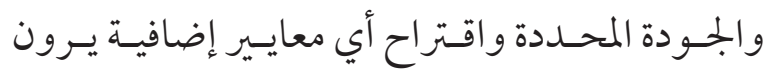

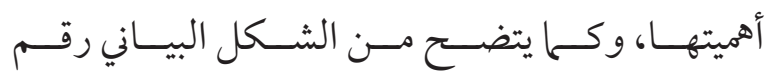

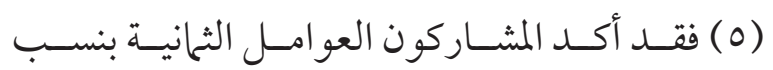

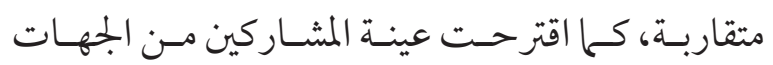

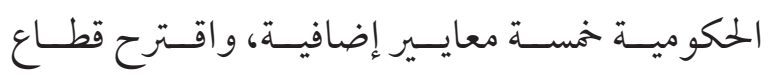

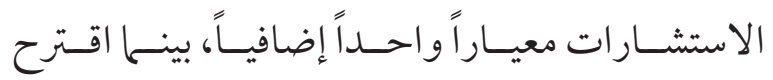
قطــاع المقـــاو لات ثلاثــة معايـيـر إضافيـة. ولمعرفــة الأهميـة النسـبية لمعايـير التقيـــم

جدول رقم (V). نتائج استجابات عينة الدراسة لمحور معاير تأهيل المقاولين في المشاريع الحكومية بالمملكة العربية السعودية واستنتاج الأوزان النسبية لكل منها

\begin{tabular}{|c|c|c|c|c|c|c|c|c|c|c|}
\hline \multicolumn{4}{|c|}{ إبجالي } & \multicolumn{2}{|c|}{ استشاري } & \multicolumn{2}{|c|}{ 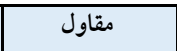 } & \multicolumn{2}{|c|}{ حكومي } & \multirow[b]{2}{*}{ 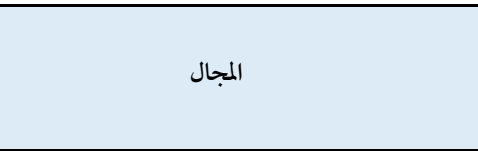 } \\
\hline بدون المنبة العامة & | النسبة العامة & 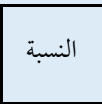 & 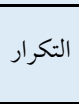 & 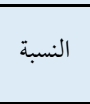 & 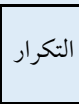 & 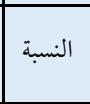 & التكرار & 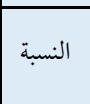 & التكرار & \\
\hline & $14.1 \%$ & $75.7 \%$ & 134 & $72.7 \%$ & 24 & $67.7 \%$ & 21 & $78.8 \%$ & 89 & الوضع المالي للمقاول \\
\hline $17.7 \%$ & $15.2 \%$ & $81.4 \%$ & 144 & $75.8 \%$ & 25 & $87.1 \%$ & 27 & $81.4 \%$ & 92 & لخبرات السابقة والمماثلة للمشروع المطروح للمناقصة \\
\hline $15.7 \%$ & $13.5 \%$ & $72.3 \%$ & 128 & $84.8 \%$ & 28 & $67.7 \%$ & 21 & $69.9 \%$ & 79 & معرفة عدد وحجم المشاريع الملتزم بها المقاول \\
\hline $13.7 \%$ & $11.7 \%$ & $62.7 \%$ & 111 & $63.6 \%$ & 21 & $51.6 \%$ & 16 & $65.5 \%$ & 74 & خبرة المقاول ومعرفته بالتنظيم الإداري والفني \\
\hline $15.0 \%$ & $12.9 \%$ & $68.9 \%$ & 122 & $78.8 \%$ & 26 & $74.2 \%$ & 23 & $64.6 \%$ & 73 & الكو ادر الإدارية والفنية العاملة بشكل دائم لدى المقاول \\
\hline $13.2 \%$ & $11.3 \%$ & $60.5 \%$ & 107 & $66.7 \%$ & 22 & $54.8 \%$ & 17 & $60.2 \%$ & 68 & المعدات والأجهزة المتوفرة لدى المقاول \\
\hline $12.1 \%$ & $10.3 \%$ & $55.4 \%$ & 98 & $78.8 \%$ & 26 & $48.4 \%$ & 15 & $50.4 \%$ & 57 & معرفة عدد المشاريع المسحوبه من المقاول \\
\hline $12.7 \%$ & $10.9 \%$ & $58.2 \%$ & 103 & $66.7 \%$ & 22 & $35.5 \%$ & 11 & $61.9 \%$ & 70 & شهادات حسن تنفيذ للمشاريع السابقة \\
\hline $100.0 \%$ & $100.0 \%$ & $535.0 \%$ & 177 & & 33 & & 31 & & 113 & 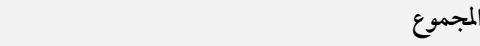 \\
\hline
\end{tabular}


السـابقة، وتـم تجميـع هـذه المعايسير تحــت تصنيفـات

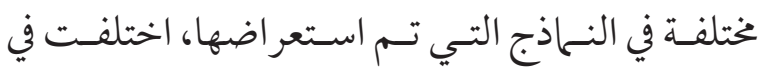

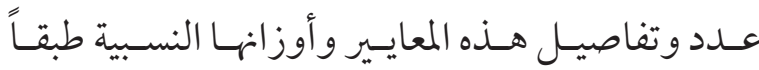

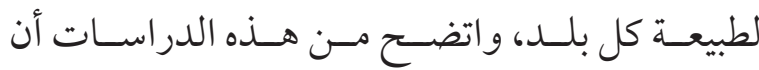

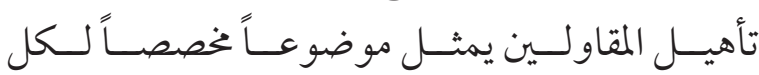

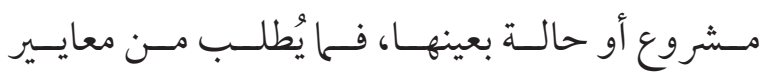

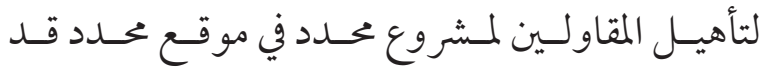

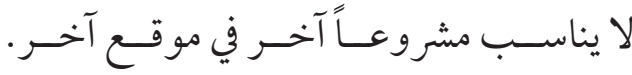

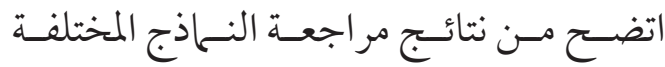
لتصنيـف وتأهيـل المقاولـــن وجــود تشـابه وتداخـل كبـير بـين معايسير تصنيـف المقاولـين في النظـام المطور لتصنيـف المقاولـين، ومعايسير تأهيل المقاولـين المحددة في نظـام المنافســات و المشـتريات الحكو ميـة الجمديـد. وهـذا و لا شـك يـؤدي إلى ازدو اجيـة الجهــود المبذولة

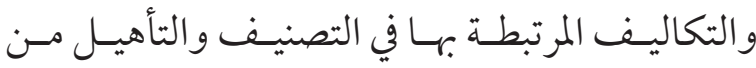
قبـل جميــع الجههـات ذات العلاقـة وهـــو مــا يعطـي مـؤشر اً بإمكانيـة دمــج عمليـات التصنيـف و التأهيـل

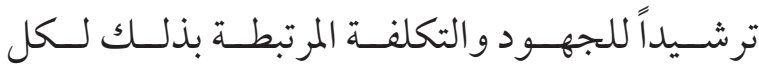
الفئـات ذات العلاقــة بهـــه العمليــات. معايسير التأهيـل المطبقــة في نظــام المنافســات

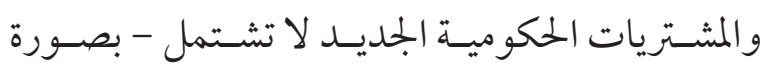

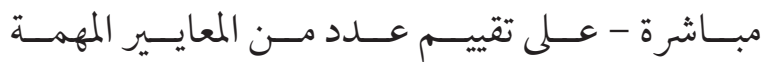

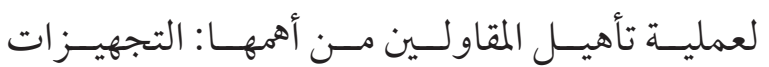
والمعــدات المملوكــة للمقــاول ووجــود قســم لصيانتهـا، وعـــدم وجــود مشــاريع متعثــرة ســابقة

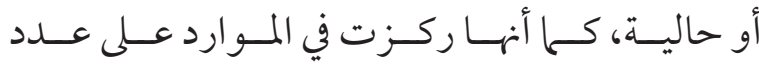

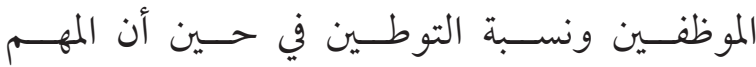
هـــو تقييـــم خـــبر ات وكفـــاءات الكــــوادر الفنيــة
المتبعــة في طــرح وترسـية المشــاريع الحكوميـة عـلى

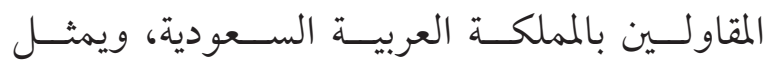

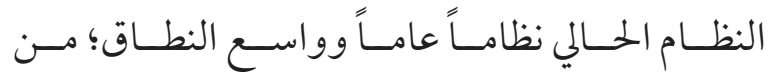
جهــة عــدم اشـتماله عــلى معايـيـر تصنيـف محسـددة

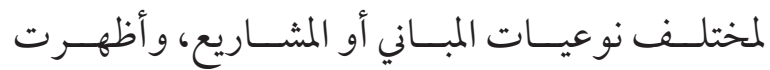

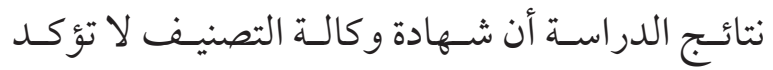

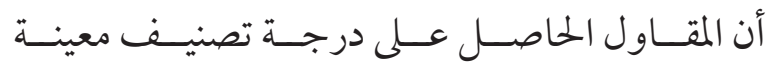
قـادر عـلى تنفيــذ المشــاريع التـي تــم تصنيفــهـ فيهـا،

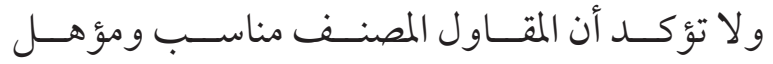
للمسـشروع المطــروح للمناقصــة. وهنــاك حاجــة لدراســة وتطويـــر معايــير التصنيـفنف بــا يحســن

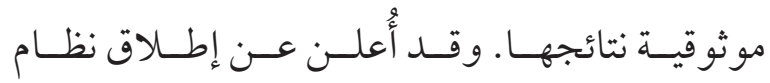

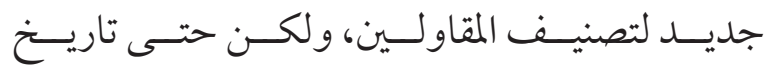

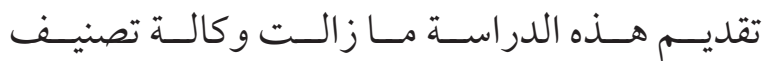
المقاولـين تعمـل عـلى تطويـر خدمـات التصنيـف ولم يتــم تفعيـل خدمــة التصنيـفــ المطــور.

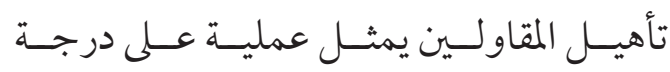

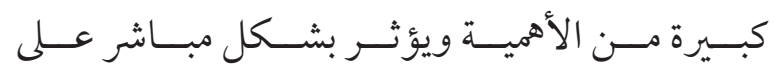
مــدى نجــاح المـشروع في تحقيـقت أهدافــه، كــا أنــهـ أحسـد أســباب رفــع مســتوى الأداء للمقــاول في تنفيـــن المشــاريع، ورفــع مســتوى المقارنــة بــين

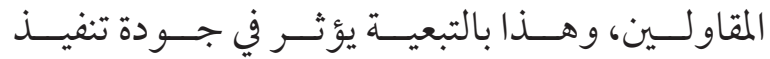

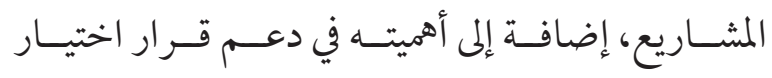

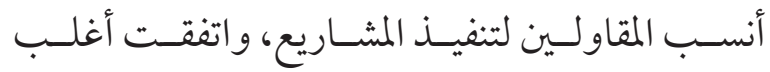

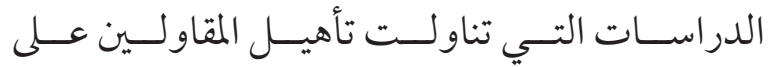

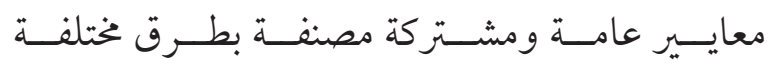
تضمنــت القـدرات الماليـة و الفنيــة والإداريــة و البيئـة و الصحســة و الســلامة ومســتوى الأداء في المشــاريع 


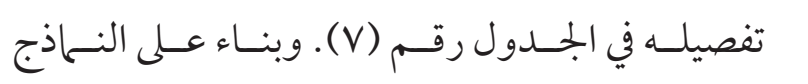

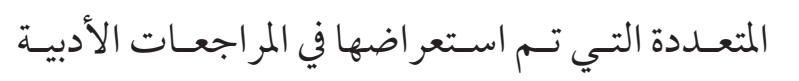

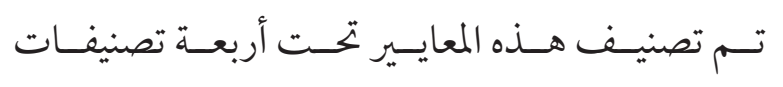

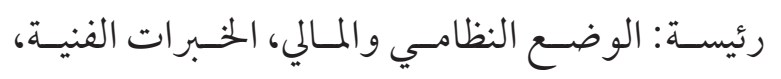

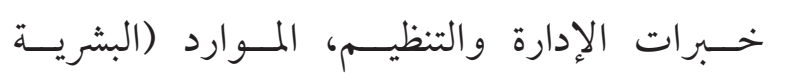

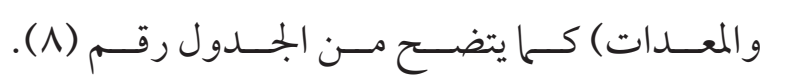

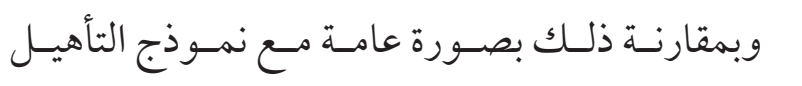

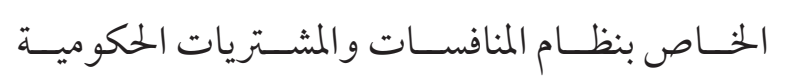

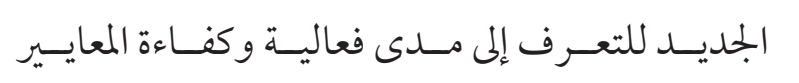

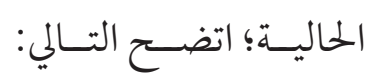

1 ا ـ معيـار الخـبرات الفنيـة: اشـتمل عـلى عــدد

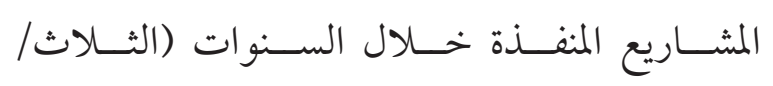

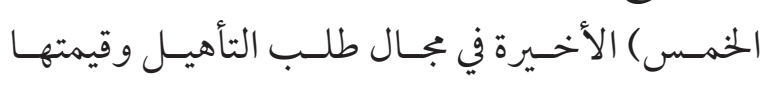

والإداريـة للمقـــاول وقدرتهــا عـلى إدارة عمليــات

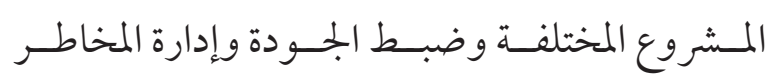

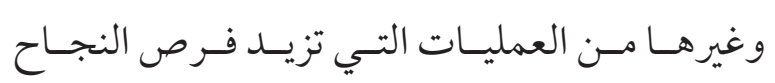
للمـشروع و ويضــاف إلى ذلــك أن تطبيـق التأهيـل

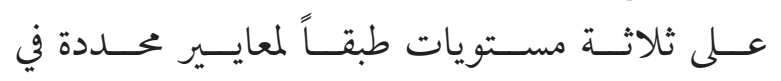

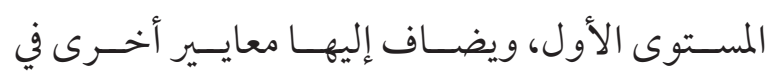

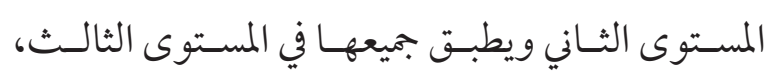

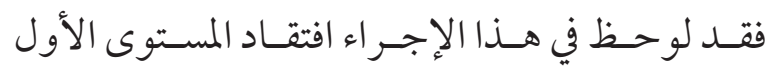

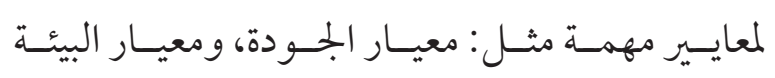

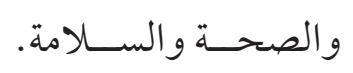

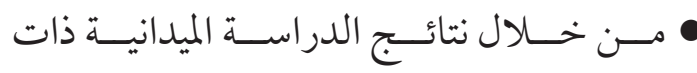

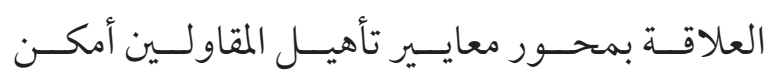

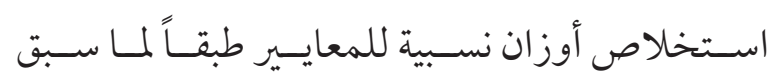

جدول رقم (^). نتيجة تقييم الدراسة الميدانية للأهمية النسبية لمعايير تأهيل المقاولين في المشاريع الحكومية

\begin{tabular}{|c|c|c|c|c|c|c|c|c|c|c|c|c|c|c|c|c|c|c|c|c|c|}
\hline \multicolumn{22}{|c|}{ معايير تأميل المقاولين والأوزان النسية لكل منها بناء كلى نائج الدراسة } \\
\hline \multicolumn{7}{|c|}{ الووارد } & \multirow{2}{*}{\multicolumn{3}{|c|}{ 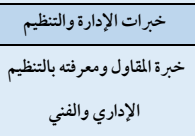 }} & \multicolumn{6}{|c|}{ الثبرات الفنية } & \multicolumn{5}{|c|}{ الوضع النظامي والملاي } & \multirow[b]{2}{*}{ الرئسيدي } \\
\hline \multicolumn{2}{|c|}{ المعدات والأجهزة } & \multicolumn{5}{|c|}{ الكوادر الإدارية الفية الساملة بشكل دائم } & & & & \multicolumn{2}{|c|}{ العقو البحارية } & \multicolumn{2}{|c|}{ |العقد السابة | } & المستوية & ل الأداء & \multicolumn{2}{|c|}{ 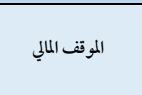 } & \multicolumn{2}{|c|}{ المقت النظامي } & |الأسلوسية & \\
\hline 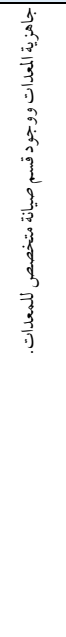 & 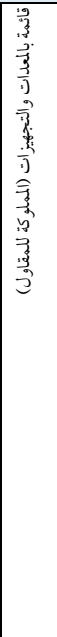 & 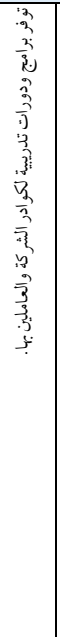 & 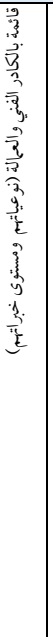 & 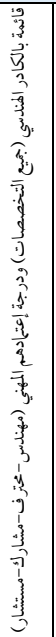 & 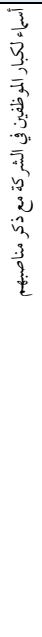 & 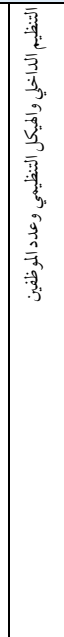 & 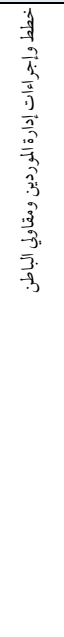 & 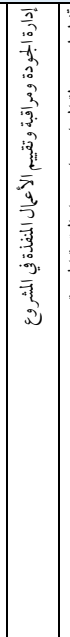 & 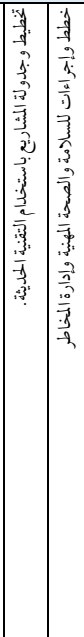 & 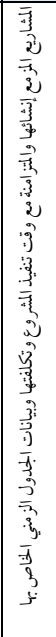 & 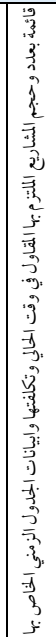 & 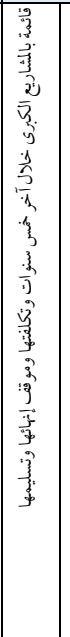 & 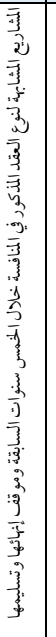 & $\begin{array}{l}\frac{3}{3} \\
\frac{3}{3} \\
3 \\
3 \\
3 \\
3 \\
3 \\
3 \\
3 \\
3 \\
3\end{array}$ & 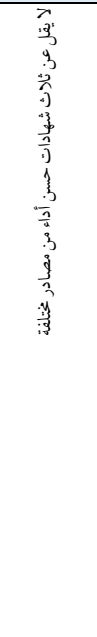 & 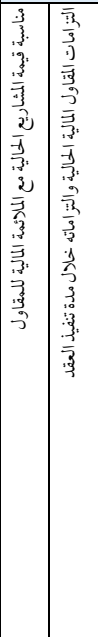 & 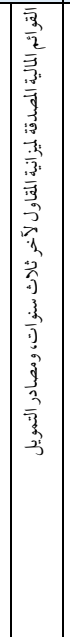 & 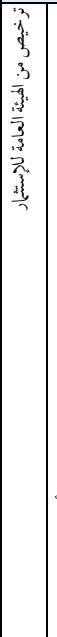 & 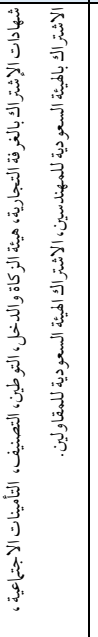 & $\begin{array}{l}3 \\
3 \\
3 \\
3 \\
3 \\
3 \\
3 \\
3 \\
3 \\
3 \\
3\end{array}$ & الثنصيلية \\
\hline \multicolumn{2}{|c|}{$11 \%$} & \multicolumn{5}{|c|}{$\begin{array}{ll}13 \% \\
\end{array}$} & \multicolumn{3}{|c|}{$12 \%$} & \multicolumn{2}{|c|}{$14 \%$} & \multicolumn{2}{|c|}{$15 \%$} & $10 \%$ & $11 \%$ & \multicolumn{2}{|c|}{$14 \%$} & \multirow{3}{*}{\multicolumn{3}{|c|}{ متطلبات إلزامية }} & \\
\hline \multicolumn{2}{|c|}{$13.2 \%$} & \multicolumn{5}{|c|}{$15.0 \%$} & \multicolumn{3}{|c|}{$13.7 \%$} & \multicolumn{2}{|c|}{$15.7 \%$} & \multicolumn{2}{|c|}{$17.7 \%$} & $12.1 \%$ & $12.7 \%$ & \multirow{2}{*}{\multicolumn{2}{|c|}{ بدون التتيمبر اللالي }} & & & & \\
\hline & & 28 & & & & & & $13 . \%$ & & & & & & & & & & & & & \\
\hline
\end{tabular}


الجــدول المقـترح لمعايـيـر التأهيـل والأوزان النسـبية

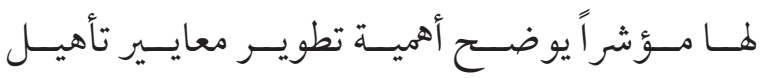

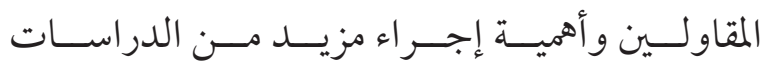
لمر اجعـة وتطويـر معايـير تصنيـف وتأهيـل المقاولـين

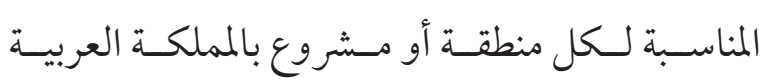
السـعودية.

\section{r , التوصيات والأبحاث المستقبلية:}

ا ـ نظـــاً لــا نتـج عـن المراجعـات الأدبيـة مـن

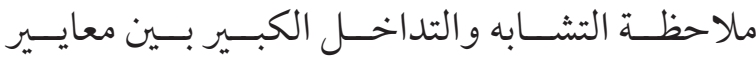
تصنيـف المقاولـين في نظــام تصنيـف المقاولـينه،

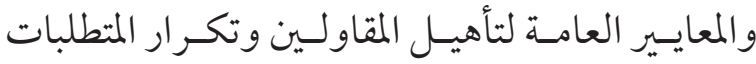

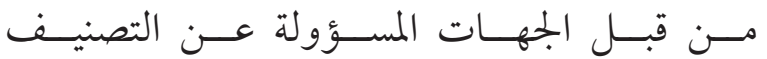

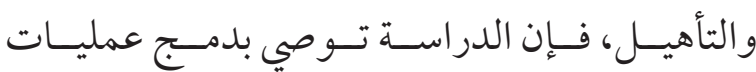

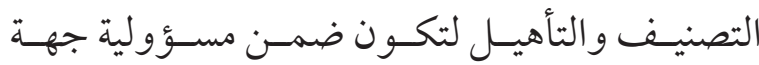

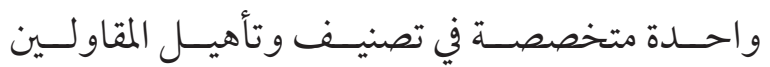

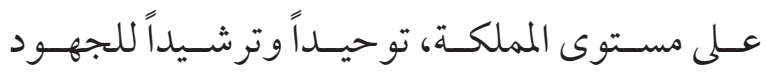

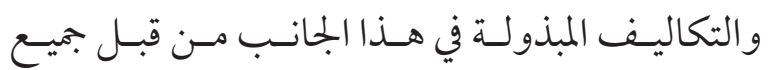

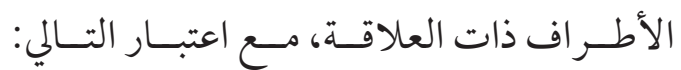

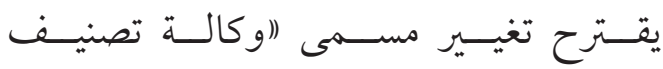

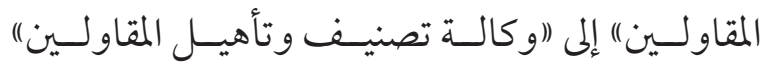

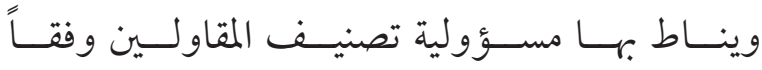

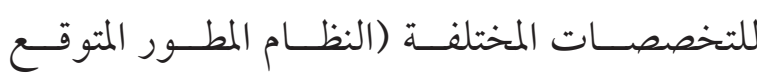

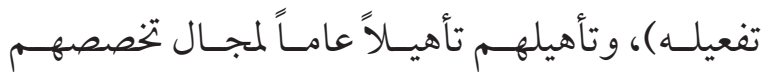

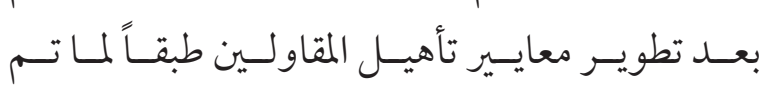
تو ضيحسـه بهـــه الدراسـة.

يقـترح أن يكــون تأهيـل المقاولـين للمشـاريع

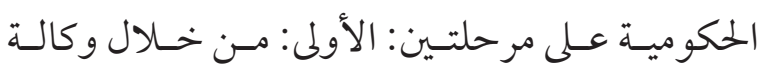

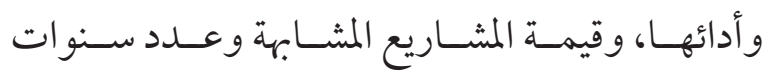

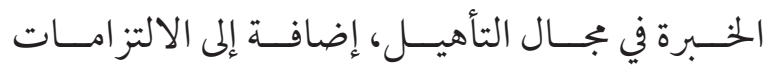

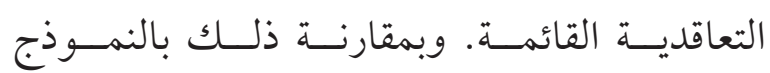

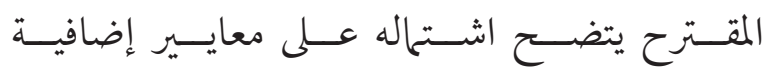

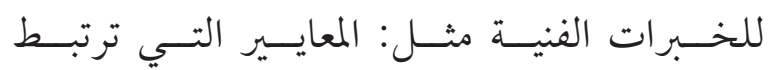

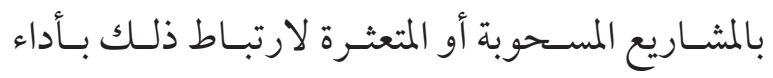

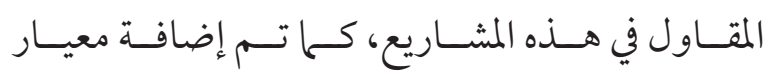

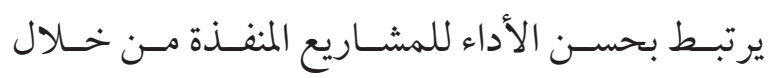

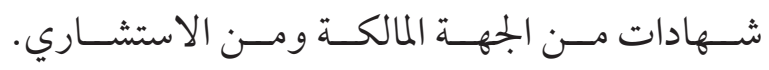
r r معايـير الخـبرات الإداريـة والتنظيم: اشـتملت

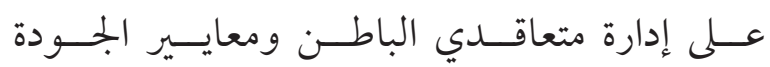

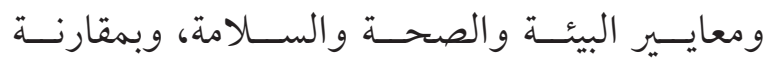

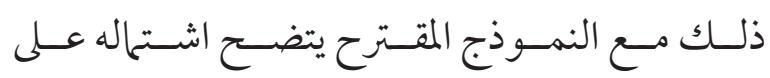

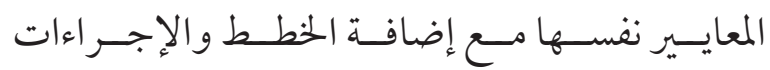
لمعايسير الجــودة والصحسـة والسـلامة، وإضافـة معيـار

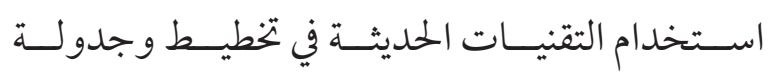
المشــاريع.

بـ المـوارد: اشـتملت عسلى المـوارد البشريـة فقـط،

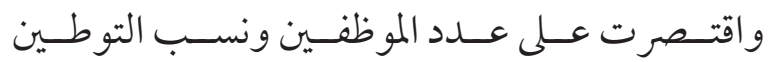

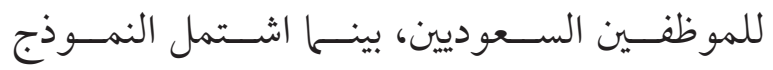

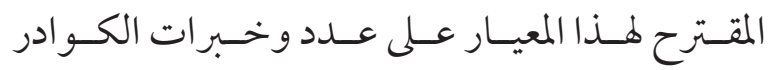

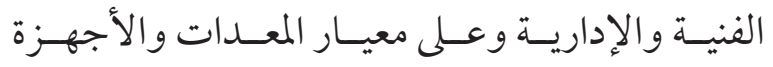

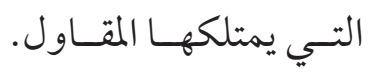

ع. (القـــدرة عـلى تقديــم التأمسين الـلازم) أدرج

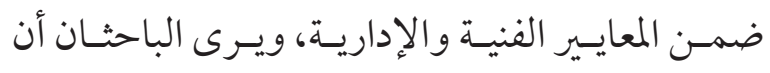
يكــون هـــا المعيـار ضمــن معيـار القــــرات الماليـة. ويمكـن اعتبـار مــا تــم التو صـل إليـه في هــــا 


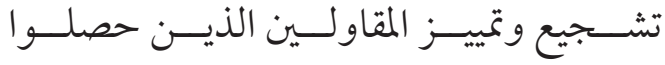

عـلى حسـن أداء متكــرر (بنظـام النقــاط عـلى ســبيل

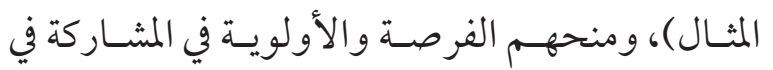
مناقصـات المشــاريع المستقتبلية. الاسـتبعاد مـن المنافسـات لمـدة عـام للمقــاول

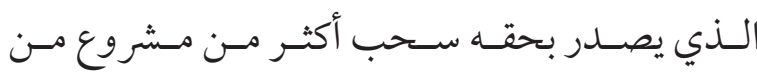

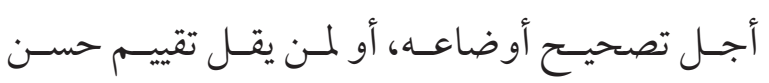

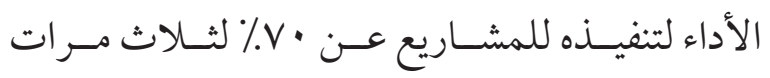
(مـع إنـاره بتحســين أوضاعـهـ في كل مـرة). r. تصميـم وإنشـاء قاعـدة بيانـات عـن المقاولـين

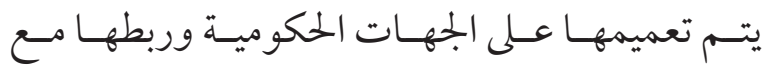

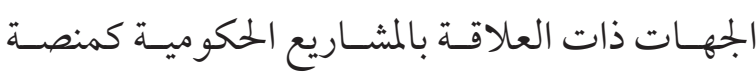

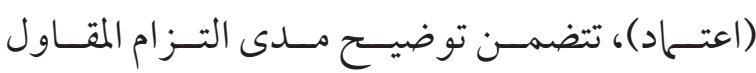

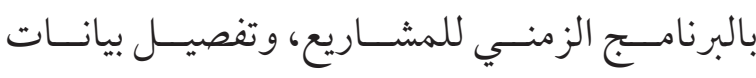

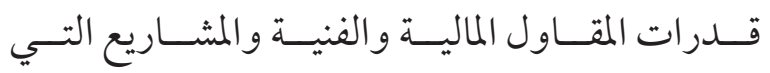
نفذهـا وتكلفتهـا خـلالال السـنوات الخمـس الماضيـة.

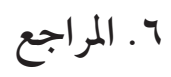

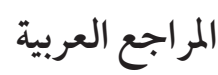

الشـاعري، فـوزي أمــد حسـين، "تحليـل وإدارة

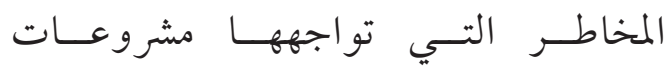

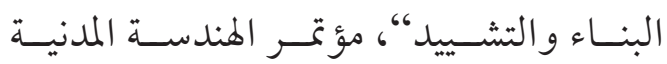
الأردني الــدولي الخامسس، نقابــة المهندســين الأردنيسين، الأردن، الأردئ الـامس، 2012م.

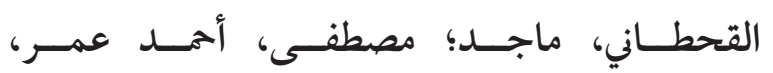

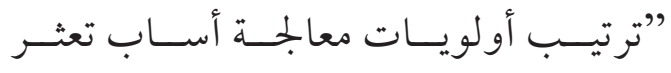

تصنيـف وتأهيـل المقاولـين (المقترحسـة)، والثانيـة:

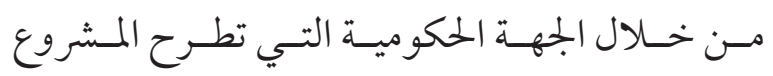

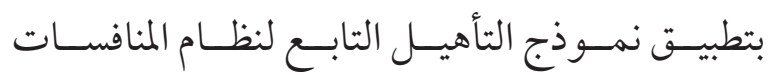

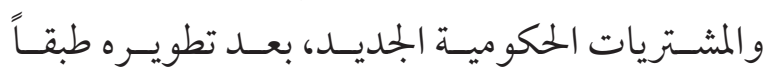

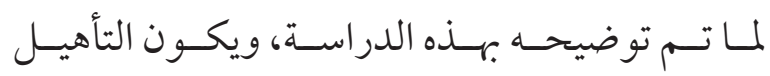

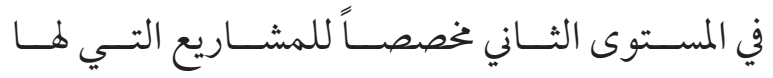

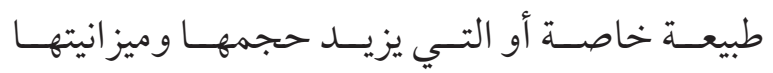

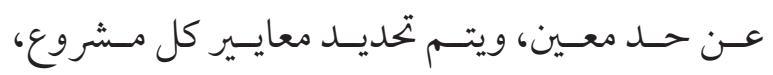

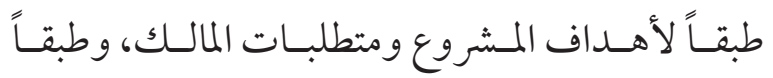

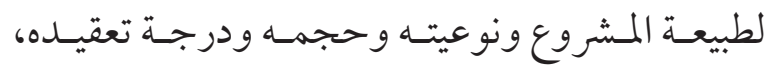

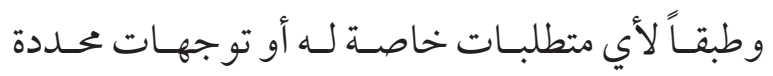

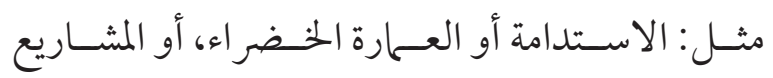

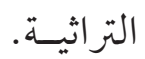

r. دعـاً لتحقيـق أهـــاف نظــام تصنيـف المقاولين

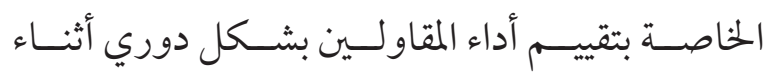

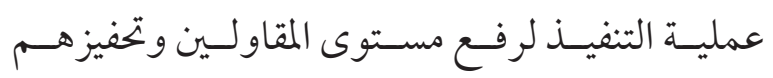

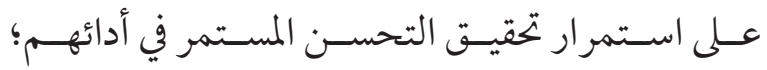
تسوصي الدراسـة بالتـالي:

• تشـكيل إدارة أو لجنـة متعــدة التخصصــات والخـبرة في كل دائـرة حكوميـة تعنسى بشـؤون تأهيـل

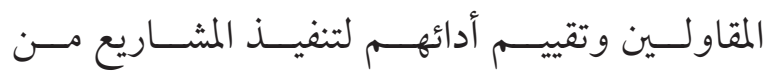

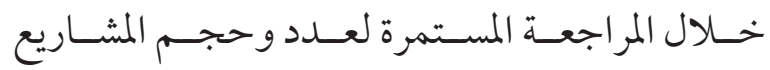

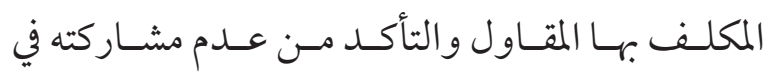

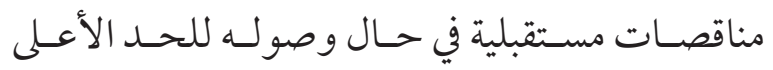
الـذي يمكنـه مـن إدارة المشــاريع وتمويلهـا وتنفيذها. تصميــم نظـام أو تقنيــة لقيـاس أداء المقــاول لــدى الجهـــات الإشر افيـة. 


$$
p r \cdot r \cdot 10 / 7
$$

نظـام تصنيــف المقاولـين، موقــع هيئــة الخـــبراء

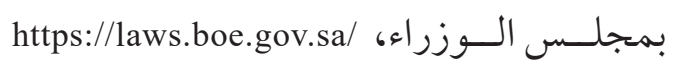

BoeLaws/Laws/LawDetails/5c351f5d-0814-

4694-86a0-a9a700f1b1f8/1

$$
p \cdot r \cdot / 0 / 7
$$

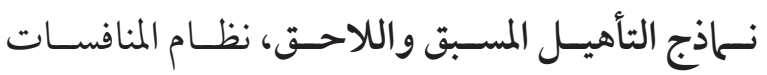

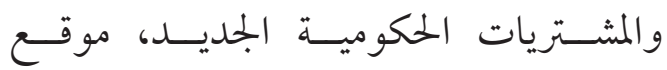

https://www.mof.gov.sa/ وزارة الماليـة

Knowledgecenter/new GovTendandPro-

cLow/Pages/Fourms.aspx

$$
. r \cdot r \cdot 10 / 7
$$

\section{Arabic References}

Al-Kahtany, Majed \& Mostafa, Ahmed Omar, "Priorities of manipulating the causes of faltering government projects during the tender and awarding phase", Al-Azhar Engineerning Journal, Al-Azhar Univerisity, 12(43): 652-663, April 2017.

Al-Shaeri, Fawzi Ahmed Hussein,"Analysis and Management of Risks facing Construction Projects", Jordanian Fifth International Civil Engineering Conference, Jordanian Engineering Sindicate, Jordon, 2012.

Arriyadh Development Authority, "Riyadh Projects' Follow-up yearly report" Riyadh Projects Follow-up Program, V14, Riyadh, 2018.

Hasan, Bassam and others, "Model Development for Contractors' prequalification", Tishreen Univerisity Journal for research and scientific studies, Syria, 28(1), 2006
المشــاريع الحلكوميـة خــلال مرحلـة الطــرح

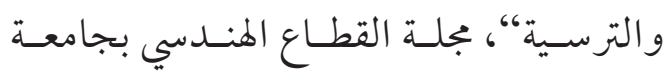

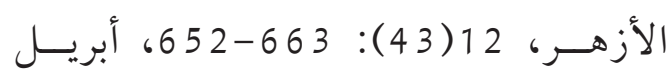

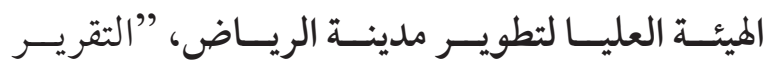

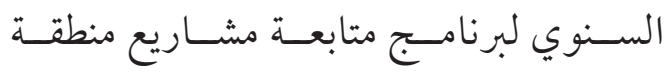

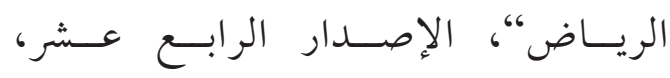

الريــاض، 2018

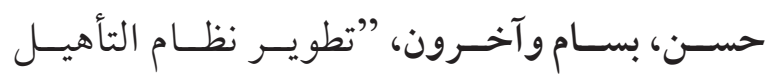

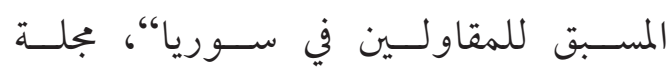

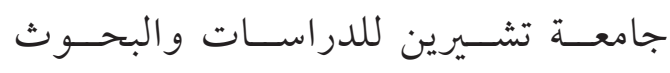

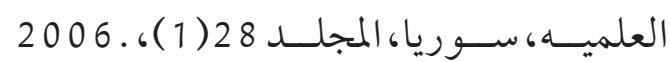

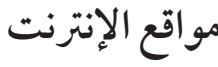

الثـيبان، إبر اهيـم، وكالـة تصنيـف المقاولـين تقلـص

معايـيـ التصنيـف إلى أربعـة، جريــدة الريـاض

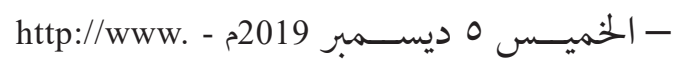

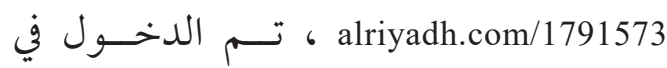

$$
p \cdot r \cdot 10 / 7
$$

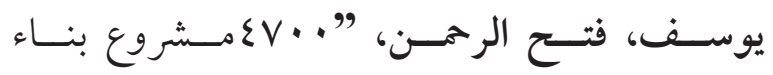

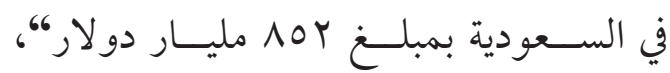

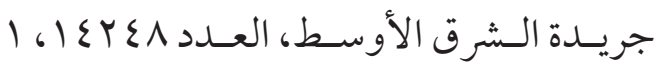

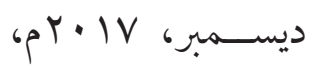

نظــام و لائحسـة تصنيــف المقاولــين، موقــع وكالــة

https:/contractors. تصنيـف المقاولـين،

momra.gov.sa/ContractorsListPage 1 .

aspx\#CAboutAgency 


$$
\text { أحمد عمر محمد سيد مصطفى؛ عبد الله بن ناصر الدبيان: تصنيف وتأهيل المقاولين في المشاريع الحكومية بالمملكة العربية السعودية. }
$$

and Architectural Management, Emerald Group Publishing Ltd, Vol. ahead-of-print No. ahead-of-print., 2020, DOI: 10.1108/ ECAM-10-2019-0543.

Lam, Ka Chi, “A support vector machine model for contractor prequalification", Automation in Construction, 18(3), 239-376, May 2009.

Mahdi, I.M., M.J. Riley, S.M. Fereig and A.P. Alex, "A Multi-criteria Approach to Contractor Selection,", Engineering, Construction and Architectural Management, 9(1): 29-37, 2002.

Michael, Almeida, "Pre-Qualification Of Contractors For High-Rise Building Projects In Philippines: A Selection Method In Construction Management Using Analytic Hierarchy Process (AHP) As A Tool In Decision Making", Presented at the DLSU Research Congress, Manila, Philippines, Vol.4, 2016.

Morkunaite, Z. et el., Contractor selection for Sgraffito decoration of cultural heritage buildings using the WASPAS-SVNS method, Sustainability (Switzerland), Volume 11, Issue 22, 1 November 2019,

Salome, Ochola Loy, "Contractor pre-qualification practices and performance of housing construction Projects in national construction authority, Kenya", International Journal of Social Science and Humanities Research, Vol. 6, Issue 3, 2018.

\section{Internet websites:}

Al-Shayban, Ibrahim, Contractor Classification Agency limits the classification Criteria to four Criteria, Riyadh newspaper, Dec., 5th, 2019, http://www.alriyadh.com/1791573, accessed on May, 6th, 2020.

Bureau of Experts at The Council of Ministers, Contractors' Classification System, https://laws.boe.gov.sa/BoeLaws/Laws/ LawDetails/5c351f5d-0814-4b94-86a0-

\section{English References}

Acheamfour, V.K. et el, "Ascertaining the impact of contractors pre-qualification criteria on project success criteria", Engineering, Construction and Architectural Management, 26 (4), 20 May 2019.

Alsugair, Abdullah, Abuthnain, Mansour, "Assessment of Government Contractor Classification System in Saudi Arabia”, Advanced Materials Research, Vols. 250-253, pp. 345355, May 2011.

Amalia, Citra and Setyohadi, Djoko, "Selection Contractors in E-Tendering Procurement of Goods and Services Bureau Central Kalimantan Using Analysis Network Process", 3rd International Conference on Energy, Environmental and Information System, ICENIS 2018; Semarang; Indonesia; 14-15 August 2018; Volume 73, 21 December 2018, Article number 13005, Code 143635.

Aysegül YILMAZ1, Sema ERGÖNÜL, "Selection of Contractors for Middle-Sized Projects in Turkey", Gazi University Journal of Science, GU J Sci, 24(3):477-485, 2011.

Azis, S. and Diliyati, "Analysis of the effect of contractor qualification on the quality of the construction project in public works agency of East Kutai district-Indonesia”, International Journal of Civil Engineering and Technology, 9(13), December 2018.

Barnes, J., "Construction Prequalification: When Project Paths Go through Electronic Gates", ENR (Engineering News-Record), 283(6), 26 August 2019

Darvish, Maryam, et al., "Application of the graph theory and matrix methods to contractor ranking", International Journal of Project Management, 27(6): 610-619, 2009.

Gurgun, A.P. \& Koc, K., “Contractor prequalification for green buildings-evidence from Turkey", Engineering, Construction 
a9a700f1b1f8/1, accessed on May, 6th, 2020.

Contractor Classification Agency, Contractors Classification System and Regulations, https://contractors.momra.gov.sa/ContractorsListPage1.aspx\#CAboutAgency, accessed on May, 6th, 2020.

Ministry of Finance, Pre and post qualification forms, the new government tendering and procurement law, https://www.mof.gov. sa/Knowledgecenter/newGovTendandProcLow/Pages/Fourms.aspx, accessed on May, 6th, 2020.

Yousef, Fath Al-Rahman, 4700 construction Projects in Saudi Arabia with a total 852 Billion Dollars", Asharq Alawsat, issue (14248), Dec., 1st, 2017, https://aawsat.com/home/ article/1099571, accessed on May, 6th, 2020 . 


\section{الملحق رقم}

\begin{tabular}{|c|c|c|c|}
\hline \multicolumn{2}{|c|}{ 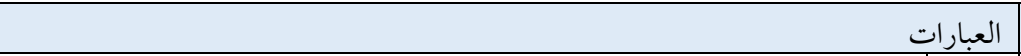 } & \multicolumn{2}{|c|}{ محور الإستبانة } \\
\hline | جهة العمل & $1-1$ & \multirow{4}{*}{ البيانات الشخصية لعينة الدراسة } & \multirow{4}{*}{.1} \\
\hline ا ت المؤهل الدراسى & $r-1$ & & \\
\hline المركز الوظيفى & $r-1$ & & \\
\hline 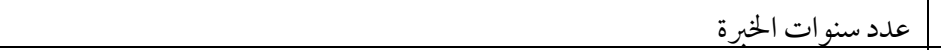 & $\varepsilon-1$ & & \\
\hline | شلماند أو والمشاريعة تصنيف المقاولين تعتبر عامة وواسعة النطاق ولا تشمل تحديد في نوعيات & $1-r$ & \multirow{3}{*}{ تصنيف المقاولين } & \multirow{3}{*}{.r } \\
\hline تنفيذ المشرو و المطرو تصنف للمناقصين لاتؤكد أن المقاول المصنف مناسب ومؤهل وقادر على & $r-r$ & & \\
\hline في تنفيذ المشاريع المشاريع لا تعكس درجة التصنيف الممنوحة للمقاول بصورة كاملة لمستوى أدائه & $r-r$ & & \\
\hline اختيار المقاول المناسب للمشروع له علاقة كبيرة بتحسين أداء تنفيذ المشروع & $1-r$ & \multirow{3}{*}{ تأهيل المقاولين: الأهمية } & \multirow{3}{*}{ r } \\
\hline اختيار المقاول المؤهل يساعد على إنهاء المشرو و وتحقيق أهدافه & $r-r$ & & \\
\hline عملية التأهيل ضرورية للتحقق من توافق قدرات المقاول مع متطلبات المشروع & $r-r$ & & \\
\hline ترتبط معايير تأهيل المقاولين بنشاط المشرو ع وحجمه، فما يُطلب من معايير لتأهيل & $1-\varepsilon$ & \multirow{5}{*}{ تحددة) تأميل اولين: المعايير (تقييم معايير } & \multirow{15}{*}{.$\varepsilon$} \\
\hline 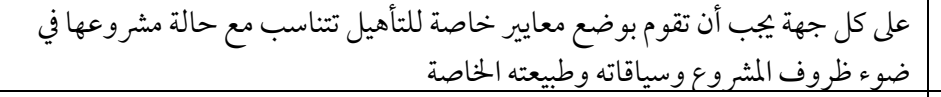 & $r-\varepsilon$ & & \\
\hline 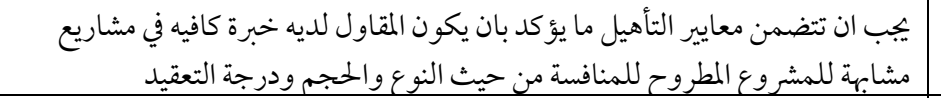 & $r-\varepsilon$ & & \\
\hline 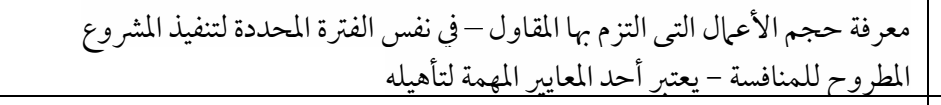 & $\varepsilon-\varepsilon$ & & \\
\hline 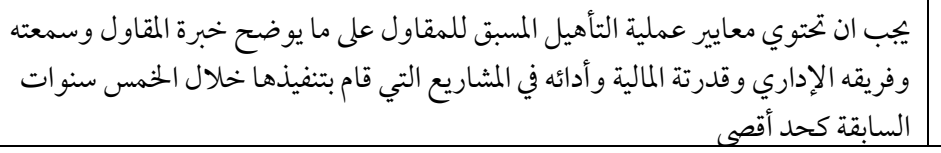 & $0-\varepsilon$ & & \\
\hline مما يلى ما تراه مها ضمن معايير التأهيل (اختيار متعدد & 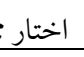 & \multirow{10}{*}{ تتعدد) المقاولين: المعايير (اختيار } & \\
\hline | الوضع الملالى للمقاول & $1-\varepsilon$ & & \\
\hline الخبرات السابقة والماثلة للمشرو و المطروح للمناقصة & $r-\varepsilon$ & & \\
\hline معرفة عدد وحجم المشاريع الملتزم بها المقاول & $r-\varepsilon$ & & \\
\hline خبرة المقاول ومعر فته بالتنظيم الإداري والفنى & $\varepsilon-\varepsilon$ & & \\
\hline الكو ادر الإدارية والفنية العاملة بشكل دائم لدى المقاول & $0-\varepsilon$ & & \\
\hline المعدات والأجهزة المتوفرة لدى المقاول & $1-\varepsilon$ & & \\
\hline معرفة عدد المشاريع المسحوبه من المقاول & $V-\varepsilon$ & & \\
\hline | شهادات حسن تنفيذ للمشاريع السابقة & $\Lambda-\varepsilon$ & & \\
\hline \multicolumn{2}{|c|}{ أي مقترحات أخرى لمعايير التأهيل التي ترى أهميتها } & & \\
\hline
\end{tabular}




\title{
Contractors' Classification and Qualification in Saudi Qovernment Projects
}

\author{
Ahmed Omar M.S. Mostafa \\ Abdullah Bin Naser Al-Dubian \\ Associate Professor \\ MSc. Student \\ Department of Architecture and Building science, College of Architecture and planning, King Saud Univer- \\ sity, Kingdom of Saudi Arabia. \\ ahmedoms@ksu.edu.sa \\ 437105960@student.ksu.edu.sa
}

Received 6/5/2020; accepted for publication 14/6/2020

\begin{abstract}
The Saudi government is keen on urban and infrastructure development projects and takes several measures to ensure their completion and use on time. One of the most important reasons for projects' success or failure is contractors. Hence, this has been one of the priorities considered by Saudi government through many actions and efforts to eliminate projects' delays and faltering, and increase the chances of projects' success. In spite of such measures and efforts, recent studies have shown that many government projects are overdue or faltered due to various reasons, $83 \%$ of which are related to contractors' technical or financial incapability. This situation was considered the main problem for this study that aims to explore the status of contractors' classification and qualification in Saudi Arabia, and the related models, criteria, and efficiency measures. The study concludes, through inductive, analytical and descriptive approaches, that the current classification and qualification criteria are almost similar and need to be developed. It is recommended that such criteria and their related procedures should be merged, and applied by a specialized classification and qualification agency. This could save money and effort, and enhance efficiency. It's also recommended that a further level of qualification should be applied by the owner government agencies, for projects of a special nature.
\end{abstract}

Key words: Government projects, Contractors' qualification, Contractors' Classification, Contractors' Classification Agency, Saudi Contractors Authority. 